\title{
Chronologic Implications for Slow Cooling of Troctolite 76535 and Temporal Relationships between the Mg-suite and the Ferroan Anorthosite Suite
}

\author{
Lars E. Borg ${ }^{1}$ \\ James N. Connelly ${ }^{2}$ \\ William Cassata ${ }^{1}$ \\ Amy M. Gaffney ${ }^{1}$ \\ Martin Bizzarro ${ }^{2}$
}

${ }^{1}$ Chemical Sciences Division, Lawrence Livermore National Laboratory, 7000 East Avenue L231, Livermore CA 94550 USA.

${ }^{2}$ Centre for Star and Planet Formation, University of Copenhagen, Øster Voldgade 5-7

Copenhagen, Denmark.

\begin{abstract}
Ages have been obtained using the ${ }^{87} \mathrm{Rb}-{ }^{87} \mathrm{Sr},{ }^{147} \mathrm{Sm}-{ }^{143} \mathrm{Nd}$, and ${ }^{146} \mathrm{Sm}-{ }^{142} \mathrm{Nd}$ isotopic systems for one of the most slowly cooled lunar rocks, Apollo $17 \mathrm{Mg}$-suite troctolite 76535. The ${ }^{147} \mathrm{Sm}^{-143} \mathrm{Nd},{ }^{146} \mathrm{Sm}^{-142} \mathrm{Nd}$, and $\mathrm{Rb}-\mathrm{Sr}$ ages derived from plagioclase, olivine, and pyroxene mineral isochrons yield concordant ages of $4307 \pm 11$ Ma, $4299^{+29} /{ }_{-35} \mathrm{Ma}$, and $4279 \pm 52 \mathrm{Ma}$, respectively. These ages are slightly younger than the age determined on ferroan anorthosite suite (FAS) rock 60025 and are therefore consistent with the traditional magma ocean model of lunar differentiation in which the $\mathrm{Mg}$-suite is intruded into the anorthositic crust. However, the Sm-Nd ages record when the rock passed below the closing temperature of the Sm-Nd system in this rock at $\sim 825$ ${ }^{\circ} \mathrm{C}$, whereas the $\mathrm{Rb}-\mathrm{Sr}$ age likely records the closure temperature of $\sim 650{ }^{\circ} \mathrm{C}$. A cooling rate of $3.9^{\circ} \mathrm{C} / \mathrm{Ma}$ is determined using the ages reported here and in the literature and calculated closure temperatures for the Ar- $\mathrm{Ar}, \mathrm{Pb}-\mathrm{Pb}, \mathrm{Rb}-\mathrm{Sr}$, and $\mathrm{Sm}-\mathrm{Nd}$ systems. This cooling rate is in good agreement with cooling rates estimated from petrographic observations. Slow cooling can lower apparent $\mathrm{Sm}-\mathrm{Nd}$ crystallization ages by up to $\sim 80$ Ma in the slowest cooled rocks like 76535 , and likely accounts for some of the variation of ages reported for lunar crustal rocks. Nevertheless, slow cooling cannot account for the overlap in FAS and Mg-suite rock ages. Instead, this overlap appears to reflect the concordance of Mg-suite and FAS magmatism in the lunar crust as indicated by ages calculated for the solidus temperature of 76535 and 60025 of $4384 \pm 24 \mathrm{Ma}$ and $4383 \pm$
\end{abstract}


17, respectively. Not only are the solidus ages of 76535 and 60025 nearly concordant, but the Sm-Nd isotopic systematics suggest they are derived from reservoirs that were minimally differentiated prior to $\sim 4.38 \mathrm{Ga}$. Although the $\mathrm{Sr}$ isotopic composition of 60025 indicates its source was minimally differentiated, the $\mathrm{Sr}$ isotopic composition of 76535 indicates it underwent fractionation just prior to solidification of the 76535 . These observations are consistent with both a magma ocean or a serial magmatism model of lunar differentiation. In either model, differentiation of lunar source regions must occur near the solidification age of thee samples. Perhaps the best estimate for the formation age of lunar source regions is the $\mathrm{Rb}-\mathrm{Sr}$ model age of the 76535 source region age of $4401 \pm 32 \mathrm{Ma}$. This is in good agreement with Sm-Nd model ages for the formation of ur-KREEP and suggests that differentiation of a least part of the Moon could not have occurred prior to $\sim 4.43 \mathrm{Ga}$.

\section{Introduction}

A general model for the formation and differentiation of the Moon has emerged from the analysis of samples collected primarily from the lunar nearside. Although this model is biased by a limited suite of samples with unique petrologic characteristics compared to rocks from the lunar farside, it successfully accounts for many geological, geochemical, and isotopic features observed on the Moon. These include the predominance of anorthosites in the lunar crust, the rare-earth element patterns observed in mare basalts, the unradiogenic Sr isotopic composition of lunar highland samples, and the extremely elevated abundances of incompatible elements observed in some lunar samples. In this model, the Moon is thought to have formed from the accretion of volatile-element depleted material produced when a Mars-sized body struck the early Earth in an event known as the Giant Impact (Hartmann and Davis, 1975; Boss and Peale, 1986). Accretion of this material to form the Moon likely produced a significant amount of heat resulting in partial (Solomon, 1986) or complete melting of the Moon (Binder, 1986; Pritchard and Stevenson, 2000), forming an ocean of magma (Wood et al., 1970; Smith et al., 1970). In this model, sequential solidification of the lunar magma 
ocean (LMO) produced a series of cumulate rocks as temperature decreased and crystallization progressed (e.g., Snyder et al., 1992). The first cumulates were olivinepyroxene rich and were followed by cumulates containing a very high proportion of plagioclase. Plagioclase is less dense than the liquid it crystallized from and consequently floated, forming a crust of ferroan anorthosites. Anorthositic crust is widespread on the Moon and makes up a significant portion of the lunar highlands. These rocks belong to the ferroan anorthosite suite (FAS) and are characterized by variable proportions of plagioclase with very high Ca contents, and mafic minerals with relatively low Mg\#. The last stages of magma ocean solidification produced cumulates that were rich in ilmenite and rocks dominated by the incompatible elements $\mathrm{K}$ (potassium), REE (rare earth elements), and P (phosphorous). These K-, REE-, and Prich residual melt (ur-KREEP) were the last primordial solidification product of the magma ocean (e.g., Warren and Wasson, 1979). A secondary crust forming episode that followed primordial solidification of the Moon has been invoked (James 1980; Norman and Ryder 1980; Warren et al., 1981) to account for the presence of intrusive rocks with the KREEP geochemical signatures and either high $\mathrm{Mg}$ contents (Mg-suite) or high $\mathrm{Fe}$ contents (Alkali-suite).

This relatively simple model of lunar differentiation and crust formation predicts that the mafic and felsic cumulates produced during primordial differentiation will predate magmatism associated with either the Mg-suite or the Alkali-suite. However, despite numerous chronologic investigations, temporal support for this scenario is largely lacking. This is illustrated on Figure 1 where it is apparent that there is little chronologic distinction between FAS and Mg-suite rocks. Note in particular that several Mg-suite rocks, such as 76535, 72417, and 15445,17, have ages that are older and outside uncertainty of the ages determined on some FAS, such as 60025 and 62236 (Papanastassiou and Wasserburg, 1975; 1976; Shih et al., 1993; Borg et al., 1999; 2011). This requires $\mathrm{Mg}$-suite magmatism to predate some FAS magmatism, a feature that is clearly contradictory to the traditional model of lunar crust formation. The discrepancy between the petrogenetic models of crust formation and the results of chronologic investigations may reflect the inability of the models to accurately reflect the geologic 
complexity of the Moon or the inability to accurately determine ages of lunar highlands rocks. Although both explanations for the discrepancy between predicted and measured ages are possible, the high level of difficulty associated with determining ages on highlands lunar samples is an obvious consideration. Borg et al. (2015) evaluated the published ages using a set of geochemical and isotopic criteria to test the possibility that the apparent overlap in ages reflected isotopic disturbances to the various chronometers used to date the rocks, but found that the best ages determined on FAS and Mg-suite rocks still overlap within uncertainty. Another consideration is the role that variable cooling rates of deep seated crustal samples play in producing the observed spread, and therefore overlap, in the apparent crystallization ages of lunar samples. The goal of this investigation is to better understand the potential spread of crustal rock ages resulting from slow cooling in the deep lunar interior. To this end, multiple isotopic systems are applied to one of the most slowly cooled lunar samples, Mg-suite troctolite 76535.

\section{Petrology and petrogenisis of 76535}

Sample 76535 is a unique $155 \mathrm{~g}$ troctolite rake sample collected during the Apollo 17 mission at Station 6 near the base of North Massif in the Taurus-Littrow valley. It is reported to have $35-58 \%$ plagioclase, 37-60\% olivine, and $~ 5 \%$ orthopyroxene (Gooley et al., 1974; Dymek et al., 1975). Minerals in 76535 have homogeneous compositions. The olivine $\left(\mathrm{Fo}_{88}\right)$ and orthopyroxene $\left(\mathrm{En}_{87} \mathrm{Fs}_{12} \mathrm{Wo}_{1}\right)$ are $\mathrm{Mg}$-rich and the plagioclase $\left(\mathrm{An}_{96}\right)$ is Ca-rich, features that are characteristic of troctolites, norites, and dunites of the $\mathrm{Mg}$-suite. This sample also has trace abundances of clinopyroxene, Cr-spinel, apatite, merilite, baddeleyite, pyrochlore, $\mathrm{K}-(\mathrm{Ba})$ feldspar, and Fe metal. Most trace minerals occur in symplectite assemblages observed along grain boundaries (Gooley et al., 1974; Dymek et al., 1975, Elardo et al., 2012). Although a variety of disparate mechanisms to produce the symplectites have been proposed, all involve slow cooling at substantial depth in the lunar interior. 
This troctolite is a very coarse-grained cumulate with individual mineral grains up to $1 \mathrm{~cm}$ in size (Haskin et al., 1974). It has a granular texture with abundant 120 degree grain boundary intersections that indicate that it cooled extremely slowly. Estimated cooling rates for 76535 are based on texture and grain size and range from $1{ }^{\circ} \mathrm{C} / \mathrm{Ma}$ (Nord, 1976) to $5^{\circ} \mathrm{C} / \mathrm{Ma}$ (Stewart, 1975). Note that these cooling rates are slow enough that they are likely to influence age determinations completed using isotopic systems with different closure temperatures. Equilibrium temperature and pressure calculated from the symplectite mineral assemblage of olivine + orthopyroxene + clinopyroxene $+\mathrm{Cr}$-spinel + plagioclase are $850 \pm 50{ }^{\circ} \mathrm{C}$ and $225 \pm 25 \mathrm{MPa}$ (McCallum \& Schwartz, 2001). This corresponds to a depth of cooling of $45 \pm 5 \mathrm{~km}$ which lies near the base of the lunar crust or in the upper mantle. McCallum et al. (2006) have used Fe-Mg ordering states in orthopyroxene to determine that the last stages of cooling below $500{ }^{\circ} \mathrm{C}$ were very rapid at $\sim 4 \times 10^{4}{ }^{\circ} \mathrm{C} / \mathrm{Ma}$. This most likely reflects cooling in an ejecta blanket after exhumation from the lunar interior. Importantly, textural evidence for post crystallization impact process, such as brecciation or melting, is lacking in 76535. Thus, evidence for isotopic disturbance in 76535 is unlikely to reflect thermal metamorphism associated with impact.

The bulk rock composition of 76535 is similar to other Mg-suite samples (Rhodes et al., 1974) and is consistent with a cumulate origin (Haskin et al. 1974). The rare earth element patterns determined for 76535 are typical of $\mathrm{Mg}$-suite rocks and are characterized by light-REE enrichment and strong positive Eu anomalies. These REE patterns are similar to those of late stage crystallization products of the lunar magma ocean, known as ur-KREEP. Most petrogenetic models for $\mathrm{Mg}$-suite involve mixing of primitive Mg-rich magma with ur-KREEP and plagioclase. Mixing has been associated with assimilation of crust, metasomatism in the mantle, or interaction between different mantle sources (e.g., Shearer et al., 2006). In any case, most petrogenetic models (e.g., Snyder et al. 1992; Shearer et al., 2006) suggest that Mg-suite rocks, such as 76535, should form after ur-KREEP and solidification of the magma ocean. 


\section{Analytical Techniques}

\subsection{Mineral separation}

Mineral fractions of 76535,11 analyzed in this investigation were produced in early 1979 at California Institute of Technology and allocated to us by D. A. Papanastassiou and G. J. Wasserburg. The fractions consisted of one plagioclase separate, 3 pyroxene separates (designated $\mathrm{A}, \mathrm{B}$, and $\mathrm{C}$ ), an olivine separate, and a dark mineral separate. The latter had plagioclase removed and was composed of olivine, pyroxene, and oxides. A general description of the mineral separation techniques that were applied to this sample is presented in Papanastassiou and Wasserburg (1976). The sample was gently crushed using a sapphire mortar and pestle. Plagioclase was handpicked from the unsieved initial crushed sample and consisted of grains $\sim 300 \mu \mathrm{m}$ in size with good cleavage and no inclusions visible under the binocular microscope. The remaining sample was further crushed and sieved to $<300 \mu \mathrm{m}$. All fractions were separated using a Frantz magnetic separator. Olivine and pyroxene were hand-picked. Cleavage and color were the basis for distinguishing these phases under the binocular microscope. The purity of the mineral separations was confirmed with analyses of representative grain populations using an electron microprobe. The pyroxene fractions were $70-90 \%$ pyroxene and $30-10 \%$ olivine. The purity of the olivine fraction was not determined using the electron microprobe, but is presumably significantly higher than the pyroxene fraction given the relative abundances of olivine in 76535 compared to pyroxene. The purity of the plagioclase fraction was visually estimated to be greater than $99 \%$.

\subsection{Digestion and mineral chemistry}

The three $\mathrm{A}, \mathrm{B}$, and $\mathrm{C}$ pyroxene fractions totaled $83 \mathrm{mg}$ and were digested along with the plagioclase $(360 \mathrm{mg})$, olivine $(467 \mathrm{mg}$ ) and two splits of the mafic mineral 
fraction (350 mg and $400 \mathrm{mg}$ ). Digestions were completed using $\mathrm{HF}, \mathrm{HNO}_{3}$, and $\mathrm{HClO}_{4}$ mineral acids in sealed Savillex beakers on a hot plate at $90^{\circ} \mathrm{C}$ at Lawrence Livermore National Laboratory (LLNL). Rare earth element abundances of mineral fractions were determined on small aliquots of the digested mineral fractions using a Thermo XSII quadrupole Inductively Coupled Plasma Mass Spectrometer at LLNL. The results are presented in Figure 2 and Table 1. Elemental concentrations were quantified by external calibration. To achieve the desired $0.1 \%$ dissolved solids content for analysis, samples were diluted with $2 \% \mathrm{HNO}_{3}$ after being digested to a clear solution. An indium internal standard was added to all samples and standards in order to correct for instrumental drift throughout the runs. The instrument response was calibrated before and after the sample block using a six point calibration curve spanning the range of concentrations in the samples. The REE abundances in the plagioclase and pyroxene fractions are similar to those determined by ion microprobe on Mg-suite norites (Papike et al., 1996). This serves to confirm the purity of the mineral separates. Note that the LREE abundances in the pyroxene fractions are higher than those measured in the norites. This likely reflects the fact that pyroxene in the norites crystalizes earlier than in the troctolites where pyroxene is one of the last minerals to crystallize. Thus, LREE enrichment of the pyroxene in the troctolites is not unexpected. The dark mineral fractions (I and II) have REE patterns intermediate between the pyroxene and the olivine consistent with the fact that they are mixtures of these two minerals.

\subsection{Chemical separations}

All samples were spiked with a mixed ${ }^{87} \mathrm{Rb}_{-}{ }^{84} \mathrm{Sr}$ tracer and a mixed ${ }^{149} \mathrm{Sm}-{ }^{150} \mathrm{Nd}$ tracer. The ${ }^{150} \mathrm{Nd}$ tracer was enriched at LLNL to $99.988 \%$ allowing ${ }^{142} \mathrm{Nd} /{ }^{144} \mathrm{Nd}$ to be measured on spiked mineral fractions without the need to correct for contributions from the spike. Samples were dried down and re-dissolved several times in $6 \mathrm{~N} \mathrm{HCl}$. Once complete dissolution was achieved, the samples were dried and then re-dissolved in $5 \mathrm{ml}$ of $2 \mathrm{~N} \mathrm{HCl}$. The samples were centrifuged to insure no solids remained undissolved. The solutions were loaded onto $26 \mathrm{~cm}$ long, $0.7 \mathrm{~cm}$ diameter primary quartz columns filled 
with AG50W-X8 200-400 mesh resin. Initial chemical separations of Rb, Sr, and REE were completed in $2 \mathrm{~N} \mathrm{HCl}, 2 \mathrm{~N} \mathrm{HNO}_{3}$, and $6 \mathrm{~N} \mathrm{HCl}$. Note that large samples were subdivided and passed through the primary columns in $\sim 200 \mathrm{mg}$ aliquots. Strontium was further purified using Sr resin $(100-150 \mu \mathrm{m}$ size $), 3 \mathrm{~N} \mathrm{HNO}_{3}$, and water. Samarium and neodymium were separated from the REE fraction from the primary cation column using $33 \mathrm{~cm}$ long, $0.1 \mathrm{~cm}$ diameter pressurized quartz columns filled with the ammonia form of AG50W-X8 200-400 mesh resin. Samples were loaded in $1 \% \mathrm{HClO}_{4}$ and eluted in $0.2 \mathrm{M}$ alpha-hydroxyisobutyric acid adjusted to a $\mathrm{pH}$ of 4.40. Neodymium was passed through these columns twice to ensure removal of Ce. Samarium and neodymium were separated from the alpha-hydroxyisobutyric acid using 2mL columns loaded with AG50W-X8 200400 resin using water, $2 \mathrm{~N} \mathrm{HCl}$, and $6 \mathrm{~N} \mathrm{HCl}$. The digestion and column procedure used here has a total blank of $8.5 \mathrm{pg} \mathrm{Rb}, 23 \mathrm{pg} \mathrm{Sr}, 17 \mathrm{pg} \mathrm{Nd}$ and $5.8 \mathrm{pg} \mathrm{Sm}$. The sample data were corrected using these procedural blanks multiplied by 1.5 times the number of passes through the primary column each sample experienced. The blank contributions had no effect on $\mathrm{Rb}-\mathrm{Sr}$ or $\mathrm{Sm}-\mathrm{Nd}$ isotopic systematics beyond analytical uncertainty.

\subsection{Mass spectrometry}

Neodymium was loaded in $2 \mathrm{~N} \mathrm{HCl}$ onto zone refined Re filaments and analyzed as $\mathrm{Nd}+$ using a second $\mathrm{Re}$ ionization filament. Isotope ratios were measured with the LLNL ThermoScientific Triton thermal ionization mass spectrometer using a two massstep procedure. This procedure calculates ${ }^{142} \mathrm{Nd} /{ }^{144} \mathrm{Nd}$ dynamically to eliminate Faraday cup biases. All other Nd isotope ratios are measured statically. Each step integrates the signal for 8 seconds leading to 16 seconds of signal integration for ${ }^{143} \mathrm{Nd} /{ }^{144} \mathrm{Nd}$ and ${ }^{148} \mathrm{Nd} /{ }^{144} \mathrm{Nd}$, and 8 second integrations for ${ }^{142} \mathrm{Nd} /{ }^{144} \mathrm{Nd},{ }^{145} \mathrm{Nd} /{ }^{144} \mathrm{Nd}$, and ${ }^{150} \mathrm{Nd} /{ }^{144} \mathrm{Nd}$. Fractionation was corrected assuming ${ }^{146} \mathrm{Nd} /{ }^{144} \mathrm{Nd}=0.7219$. For the plagioclase, 1080 ratios were obtained at an average ${ }^{144} \mathrm{Nd}=4.2 \times 10^{-11}$ amps (measured using $10^{-11} \mathrm{ohm}$ resistors). The pyroxene produced 240 ratios at an average ${ }^{142} \mathrm{Nd}=7 \times 10^{-12}$ amps. The dark mineral fractions I and II ran for 420 and 320 ratios, respectively at an average of

${ }^{144} \mathrm{Nd}=1-2 \times 10^{-12}$ amps of ${ }^{144} \mathrm{Nd}$. Errors reported for the sample measurements are the 
$2 \sigma$-mean from the individual mass spectrometer runs. Four 540 ratio runs of the JNdi Nd standard were run in the same barrel as the sample analyses at signal sizes of ${ }^{144} \mathrm{Nd}=3.8$ to $4.5 \times 10^{-11}$ amps. The average isotopic composition of the standard was measured to be ${ }^{142} \mathrm{Nd} /{ }^{144} \mathrm{Nd}=1.141838 \pm 5,{ }^{143} \mathrm{Nd} /{ }^{144} \mathrm{Nd}=0.512102 \pm 3,{ }^{145} \mathrm{Nd} /{ }^{144} \mathrm{Nd}=0.348403 \pm 2$, ${ }^{148} \mathrm{Nd} /{ }^{144} \mathrm{Nd}=0.241580 \pm 3$, and ${ }^{150} \mathrm{Nd} /{ }^{144} \mathrm{Nd}=0.236456 \pm 6$ (errors refer to last digits and are $2 \mathrm{x}$ standard deviation of the standard runs). These values are in excellent agreement with our long-term average values determined on 37 runs of the JNdi standard of $1.141839 \pm 7,0.512101 \pm 5,0.348401 \pm 4$ and $0.241583 \pm 6$. Interferences from $\mathrm{Ce}$ and $\mathrm{Sm}$ are monitored at ${ }^{140} \mathrm{Ce}$ and ${ }^{149} \mathrm{Sm}$. Interference from $\mathrm{Sm}$ was as high as ${ }^{144} \mathrm{Sm} /{ }^{144} \mathrm{Nd}=15 \mathrm{ppm}$ for the pyroxene but was below $3 \mathrm{ppm}$ for the analyses of plagioclase and the dark mineral factions. Cerium interference $\left({ }^{142} \mathrm{Ce} /{ }^{142} \mathrm{Nd}\right)$ was $16 \mathrm{ppm}$ for plagioclase, $14 \mathrm{ppm}$ for pyroxene and 48 and $58 \mathrm{ppm}$ for the dark mineral fractions I and II, respectively. Corrections for these interferences are applied using natural $\mathrm{Ce}$ and Sm isotopic compositions.

Samarium was loaded in $2 \mathrm{~N} \mathrm{HCl}$ onto a zone refined Re filament and analyzed as $\mathrm{Sm}+$ using double Re filaments. All Sm isotopes along with interferences from $\mathrm{Nd}$ $\left({ }^{146} \mathrm{Nd}\right)$ were measured statically for 200 ratios of 8 seconds integration each. Instrument fractionation was corrected assuming ${ }^{147} \mathrm{Sm} /{ }^{152} \mathrm{Sm}=0.56803$. Samarium concentrations were calculated using the Sm isotopic composition determined from an unspiked plagioclase fraction. The unspiked plagioclase was run at $0.4 \times 10^{-11}$ amps of ${ }^{149} \mathrm{Sm}$ for 400 ratios and demonstrated deviations from natural $\mathrm{Sm}$ of $\varepsilon^{149} \mathrm{Sm}=-16.5 \pm 0.10$ and $\varepsilon^{150} \mathrm{Sm}=+26.7 \pm 0.15$ as a result of the capture of thermal neutrons that occurred on the lunar surface. Although we did not have a whole rock fraction to use for this measurement, the $\mathrm{Sm}$ isotopic composition of the plagioclase was representative of the whole rock as demonstrated by the good agreement of our measurement Sm isotopic composition with previously determined whole rock values (Lugmair et al. 1976). Neodymium was corrected for neutron capture following Nyquist et al. (1995). 
Rubidium was loaded on single zone refined Re filaments in $2 \mathrm{~N} \mathrm{HCl}$ with a 99.999\% pure $\mathrm{Ta}_{2} \mathrm{O}_{5}$ emitter suspended in $0.5 \mathrm{M} \mathrm{H}_{3} \mathrm{PO}_{4}$. Fractionation was corrected using runs of NBS-984 completed during the course of the investigation. Strontium was also loaded on single zone refined Re filaments in $2 \mathrm{~N} \mathrm{HCl}$ with the $\mathrm{Ta}_{2} \mathrm{O}_{5}$ emitter and run at $1-7 \times 10^{-11}$ amps ${ }^{88} \mathrm{Sr}$ for 200 ratios of 8 second integrations. Fractionation was corrected assuming ${ }^{86} \mathrm{Sr} /{ }^{88} \mathrm{Sr}=0.1194$. Although ${ }^{87} \mathrm{Rb}$ was monitored during the analyses no corrections were needed. Four 200 ratio analyses of the NBS-987 standard run at 3 to $5 \times 10^{-11}$ amps of ${ }^{88} \mathrm{Sr}$ were run in the same barrel as the sample analyses and averaged ${ }^{87} \mathrm{Sr} /{ }^{86} \mathrm{Sr}=0.710242 \pm 10$. This value agrees with our long-term ${ }^{87} \mathrm{Sr} /{ }^{86} \mathrm{Sr}$ value determined on 100 runs of NBS-987 of $0.710247 \pm 9$.

\section{Results}

\subsection{Sm-Nd age}

Samarium-neodymium data are presented in Table 2 and plotted on isochron diagrams (Figures 3A and 3B). The ${ }^{147} \mathrm{Sm}^{-1}{ }^{143} \mathrm{Nd}$ isochron defines an age of $4307 \pm 11$ Ma with all four mineral fractions, and yields an initial $\varepsilon^{143} \mathrm{Nd}$ of $-0.16 \pm 0.15$. The regression fits the data very well as demonstrated by a low MSWD of 1.4. The low uncertainty associated with this age reflects a combination of having only 4 mineral fractions to define the isochron and the relatively high precision of the $\mathrm{Nd}$ isotopic measurements that were obtained with long duration measurements. The slope of the line regressed through the mineral fraction data on the ${ }^{147} \mathrm{Sm} /{ }^{144} \mathrm{Nd}-{ }^{142} \mathrm{Nd} /{ }^{144} \mathrm{Nd}$ isochron plot (Figure 3B) is $0.00028 \pm 0.00006$ and has a MSWD of 0.6. This isochron has an initial $\varepsilon^{142} \mathrm{Nd}$ (relative to the modern terrestrial ${ }^{142} \mathrm{Nd} /{ }^{144} \mathrm{Nd}$ ) of $-0.60 \pm 0.12$ that is consistent with a young age of 76535. An age calculated from the slope of the isochron is $4299^{+29}$. $35 \mathrm{Ma}$ and is concordant with the ${ }^{147} \mathrm{Sm}-{ }^{143} \mathrm{Nd}$ age of $4307 \pm 11 \mathrm{Ma} . \quad \mathrm{A}^{142} \mathrm{Nd}-{ }^{143} \mathrm{Nd}$ isochron yields a slope of $0.0098 \pm 0.0020$ which, following Borg et al., (2016), 
corresponds to an age of $4303{ }^{+28} /-36$ Ma. Both the ${ }^{146} \mathrm{Sm}^{-{ }^{142}} \mathrm{Nd}$ and ${ }^{143} \mathrm{Nd}-{ }^{142} \mathrm{Nd}$ ages are calculated using the traditional $103 \mathrm{Ma}$ half-life and initial Solar System ${ }^{146} \mathrm{Sm} /{ }^{144} \mathrm{Sm}$ ratio of 0.00828 determined by Marks et al. (2014a), rather than the recently published values of ${ }^{146} \mathrm{Sm} \mathrm{t} \mathrm{t}_{1 / 2}=68 \mathrm{Ma}$ and ${ }^{146} \mathrm{Sm} /{ }^{144} \mathrm{Sm}$ of 0.0094 (Kinoshita el al., 2012). A ${ }^{146} \mathrm{Sm}$ ${ }^{142} \mathrm{Nd}$ age of $4379{ }^{+19} /{ }_{-23}$ Ma that is discordant from the ${ }^{147} \mathrm{Sm}-{ }^{143} \mathrm{Nd}$ age is calculated using the half-life and initial Solar System ${ }^{146} \mathrm{Sm} /{ }^{144} \mathrm{Sm}$ proposed by Kinoshita et al. (2012). Similar discordancy is observed between ${ }^{146} \mathrm{Sm}-{ }^{142} \mathrm{Nd}$ ages calculated using the parameters proposed by Kinoshita et al. (2012) and long-lived chronometric systems, such as ${ }^{147} \mathrm{Sm}^{143} \mathrm{Nd}$ and $\mathrm{Pb}-\mathrm{Pb}$, determined on other lunar and meteorites samples suggesting that the half-life proposed by Kinoshita et al. (2012) may be incorrect (Marks et al., 2014a).

The Sm-Nd ages do not appear to have been disturbed significantly by postcrystallization processes such as impact metamorphism. All mineral fractions analyzed lie on the ${ }^{147} \mathrm{Sm}_{-}{ }^{143} \mathrm{Nd}$ and ${ }^{146} \mathrm{Sm}_{-}{ }^{142} \mathrm{Nd}$ isochrons and ages determined from both systems are concordant. The fit of the data to the regression is very good as indicated by MSWD of $\sim 2$ or less. In addition, the initial $\varepsilon N d$ values determined by both isotopic systems are slightly negative indicative of derivation from a source region with light-REE enriched to chondritic REE abundances, as predicted from petrogenetic investigations of $\mathrm{Mg}$-suite rocks (e.g., Snyder et al., 1995; Shearer et al., 2006). Finally, the rare earth element abundances measured in the mineral fractions by quadrupole ICP-MS match the concentrations determined by isotope dilution and are similar to those measured for other $\mathrm{Mg}$-suite rocks by secondary ion mass spectrometry (Figure 2; Tables 1 and 2), indicating extraneous minerals, minerals disturbed by impact processes, or impact melts were not incorporated into the mineral fractions in significant quantities.

The ${ }^{147} \mathrm{Sm}-{ }^{143} \mathrm{Nd}$ and ${ }^{146} \mathrm{Sm}-{ }^{142} \mathrm{Nd}$ ages determined in this investigation appear to be in good agreement with previously published Sm-Nd ages. However, it is difficult to directly compare ages determined by different laboratories because measurements were completed using different normalization schemes, values determined on $\mathrm{Nd}$ standards 
were different, and regression programs used to calculate the ages are different (e.g., York 1966; Williamson, 1968). In order to compare ages and initial isotopic compositions more directly, Borg et al. (2015) renormalized published isotopic data to common standard values and recalculated ages of lunar highlands samples using a common regression program (IsoPlot 4.15). The ages recalculated by Borg et al. (2015) are used in this age comparison.

The ${ }^{147} \mathrm{Sm}-{ }^{143} \mathrm{Nd}$ age of $4307 \pm 11$ Ma determined here is within error of ${ }^{147} \mathrm{Sm}-$ ${ }^{143} \mathrm{Nd}$ age reported by Nyquist et al. (2012) of $4335 \pm 71 \mathrm{Ma}$, and recalculated from the data of Premo and Tatsumoto (1992) of $4330 \pm 64 \mathrm{Ma}$, and from Lugmair et al. (1976) of $4253 \pm 52 \mathrm{Ma}$. The initial $\varepsilon^{143} \mathrm{Nd}$ values determined by the four studies are also in fairly good agreement. In fact, after renormalization to common Nd standards two of the three previous studies yield initial $\varepsilon^{143} \mathrm{Nd}$ values of $+0.23 \pm 0.44$ (Nyquist et al., 2012) and $+0.16 \pm 0.48$ (Lugmair et al. 1976) that are within uncertainty of the $-0.16 \pm 0.15$ values reported here. The only notable exception is the initial $\varepsilon^{143} \mathrm{Nd}$ value determined by Premo and Tatsumoto (1992) which is $-1.25 \pm 0.44$. In contrast, the ${ }^{146} \mathrm{Sm}_{-}{ }^{142} \mathrm{Nd}$ age determined on 76535 of $4299^{+29} /_{-35}$ Ma in this study is not concordant with the ${ }^{146} \mathrm{Sm}$ ${ }^{142} \mathrm{Nd}$ age of $4439 \pm 22 \mathrm{Ma}$ reported by Nyquist et al. (2012). The ${ }^{146} \mathrm{Sm}-{ }^{142} \mathrm{Nd}$ age reported by Nyquist et al. (2012) is also discordant from the ${ }^{147} \mathrm{Sm}^{-143} \mathrm{Nd}$ age they determined using the same mineral fractions, suggesting their ${ }^{146} \mathrm{Sm}_{-}{ }^{142} \mathrm{Nd}$ age may be disturbed. Nevertheless, despite some differences in the $\mathrm{Sm}-\mathrm{Nd}$ isotopic systematics of 76535 reported by the various investigations, the overall agreement suggests that the Sm$\mathrm{Nd}$ age of 76535 records the closure of the Sm-Nd system that occurred during initial solidification of the troctolite.

\subsection{Rb-Sr age}

Rubidium-strontium isotopic analyses were completed on the same fractions that were analyzed for Sm-Nd isotopic compositions. An additional olivine fraction was 
included in the $\mathrm{Rb}-\mathrm{Sr}$ analyses that could not be analyzed for $\mathrm{Sm}-\mathrm{Nd}$ because the $\mathrm{Nd}$ abundance was too low. The Rb-Sr data are presented in Figure 4 and Table 3. A four point isochron defined by plagioclase, olivine, and the two dark mineral fractions has a slope corresponding to an age of $4279 \pm 52$ Ma with a MSWD of 2.2. The pyroxene fraction lies to the right of the $4279 \mathrm{Ma}$ isochron defined by the other mineral fractions indicating that it is isotopically disturbed. This disturbance could be produced by an analytical issue, such as contamination of pyroxene $\mathrm{Rb}$ aliquot during dry-down on the hot plate, or reflect the mobility of $\mathrm{Rb}$ during slow cooling of the rock. Although previous investigations completed on lunar samples have demonstrated that $\mathrm{Rb}$ in pyroxene is particularly mobile during shock metamorphism (Borg et al., 1999), 76535 appears to be unshocked. Furthermore, the fact that the dark mineral fractions contain pyroxene and lie on the isochron, suggests that the pyroxene $\mathrm{Rb}$ aliquot suffered from $\mathrm{Rb}$ contamination.

Despite this disturbance, the $4279 \mathrm{Ma}$ age defined by the other fractions is interpreted to best record the $\mathrm{Rb}-\mathrm{Sr}$ age of 76535 because it includes the majority of analyzed fractions. The $4279 \mathrm{Ma}$ age reported here is slightly younger, but concordant with the $\mathrm{Sm}-\mathrm{Nd}$ ages determined for this sample. The $\mathrm{Rb}-\mathrm{Sr}$ data obtained on troctolite 76535 by Papasastassiou and Wasserburg (1976) and Premo and Tatsumoto (1992) are in general agreement with the data obtained here and fall on both sides of the $4279 \mathrm{Ma}$ isochron. Nevertheless, the $\mathrm{Rb}-\mathrm{Sr}$ age reported by Papasastassiou and Wasserburg (1976) of $4568 \pm 85$ Ma differs significantly from the age reported here. The significance of the old age is unclear.

The concordance between the $\mathrm{Rb}-\mathrm{Sr}$ and $\mathrm{Sm}-\mathrm{Nd}$ ages reported here suggests that the $\mathrm{Rb}-\mathrm{Sr}$ age could preserve a record of when 76535 cooled below the closure temperature of these systems. The initial ${ }^{87} \mathrm{Sr} /{ }^{86} \mathrm{Sr}$ ratio defined by the plagioclase, olivine, and combined Dark Mineral Fractions is $0.699100 \pm 0.000009$ and is in excellent agreement with the initial $\mathrm{Sr}$ isotopic composition recalculated from the data of Papasastassiou and Wasserburg (1976) of $0.699098 \pm 0.000075$. The good agreement between measured initial $\mathrm{Sr}$ isotopic compositions reflects the fact that they are essentially defined by the isotopic composition of the plagioclase mineral fraction and consequently require very little correction for radiogenic growth. Thus, the initial 
${ }^{87} \mathrm{Sr} /{ }^{86} \mathrm{Sr}$ ratio of 0.699110 derived from the isochron is an accurate representation of the 76535 source region at $\sim 4300 \mathrm{Ma}$.

\section{Discussion}

\subsection{Cooling rate of 76535}

A variety of radiogenic ages have been determined for troctolite 76535 including $4320 \pm 20 \mathrm{Ma}$ (2 sigma uncertainty) by Ar-Ar (Cassata and Borg, 2015), $4226 \pm 35 \mathrm{Ma}$ by $\mathrm{Pb}-\mathrm{Pb}$ on plagioclase fractions (Premo and Tatsumoto, 1992), as well as $4249 \pm 52 \mathrm{Ma}$ and $4307 \pm 11 \mathrm{Ma}$ by internal $\mathrm{Rb}-\mathrm{Sr}$ and $\mathrm{Sm}-\mathrm{Nd}$ isochron analysis (reported here). Because 76535 is one of the most slowly cooled lunar samples it has been suggested that this range of ages might reflect variable closure temperatures for the different isotopic systems (McCallum and Schwartz, 2001; McCallum et al., 2006; Elardo et al., 2012). In order to evaluate this possibility the closure temperatures of the $\mathrm{Rb}-\mathrm{Sr}, \mathrm{Sm}-\mathrm{Nd}$, and $\mathrm{Pb}$ $\mathrm{Pb}$ isotopic systems in plagioclase and orthopyroxene have been calculated using equations first proposed by Dodson $(1973,1986)$ and modified by Ganguly and Tirone (1999), using the Arrhenius relations obtained by Cherniak and Watson (1994), Cherniak (1995, 2003), Cherniak and Liang (2007). The Pb-Pb age of Premo and Tatsumoto (1992) was based on the analysis of plagioclase, whereas the $\mathrm{Rb}-\mathrm{Sr}$ and $\mathrm{Sm}-\mathrm{Nd}$ ages presented here are based on isotopic analysis of plagioclase-olivine, and plagioclasepyroxene, respectively. The closure temperature for $\mathrm{Pb}-\mathrm{Pb}, \mathrm{Rb}-\mathrm{Sr}$, and $\mathrm{Sm}-\mathrm{Nd}$ system in 76535 presented here are based on Arrhenius relations determined on plagioclase either because it has the highest closure temperature of any mineral used to define the age (Sm$\mathrm{Nd}$ system), it was the sole phase used to define the age ( $\mathrm{Pb}-\mathrm{Pb}$ system), or because it is the only phase on the isochron for which diffusion data have been determined ( $\mathrm{Rb}-\mathrm{Sr}$ system).

The closure temperature estimated for the $\mathrm{Pb}-\mathrm{Pb}$ system in plagioclase from 76535 is estimated to be $624 \pm 9{ }^{\circ} \mathrm{C}$, the closure temperature estimated for the $\mathrm{Rb}-\mathrm{Sr}$ 
system is $649 \pm 15^{\circ} \mathrm{C}$, and the closure temperature for $\mathrm{Sm}-\mathrm{Nd}$ is $825 \pm 15^{\circ} \mathrm{C}$. Note that the closure temperature of the $\mathrm{Sm}-\mathrm{Nd}$ system for the plagioclase of $825^{\circ} \mathrm{C}$ is within uncertainty of the $799 \pm 67^{\circ} \mathrm{C}$ closure temperature estimate for orthopyroxene. Also relevant to this discussion is the Ar-Ar system that defines the relatively well constrained closure temperature of Ar diffusion. Diffusion studies completed on 76535 by Cassata and Renne (2013) demonstrate 76535 closed to Ar diffusion at $300 \pm 50{ }^{\circ} \mathrm{C}$. Textural studies of 76535 by McCallum et al. (2006), however, indicate that the cooling rate was extremely rapid starting at $500 \pm 50^{\circ} \mathrm{C}$. Thus, the Ar-Ar age essentially records the onset of rapid cooling that began at $\sim 500{ }^{\circ} \mathrm{C}$. Husain and Schaeffer (1975) suggested this reflected impact excavation of 76535. Note that all of these closure temperatures are below the equilibrium temperature of the major phases in the rock of $\sim 850 \pm 50{ }^{\circ} \mathrm{C}$ (McCallum and Schwartz, 2001) so that protracted cooling could result in mineral ages that record events occurring after the rock solidified.

The cooling rate of 76535 is estimated using the calculated closure temperatures and ages determined using the $\mathrm{Ar}-\mathrm{Ar}, \mathrm{Pb}-\mathrm{Pb}, \mathrm{Rb}-\mathrm{Sr}$, and $\mathrm{Sm}-\mathrm{Nd}$ isotopic systems (Figure $5)$. When plotted, these data form a linear trend on Figure 5 with a slope corresponding to an average cooling rate of $3.9 \pm 1.2{ }^{\circ} \mathrm{C} / \mathrm{Ma}$ over the interval from $\sim 825$ to $500{ }^{\circ} \mathrm{C}$. The slope calculated using the IsoPlot (v. 4.15) program and has a MSWD of 1.8. This cooling rate is in good agreement with cooling rates of 1 to $5^{\circ} \mathrm{C} / \mathrm{Ma}$ determined for this sample based on its petrologic characteristics (Nord et al., 1976; Stewart, 1975). The linearity of the regression on Figure 5 suggests that the cooling rate was essentially constant for $\sim 75 \mathrm{Ma}$, as might be expected over a relatively small temperature interval of $325{ }^{\circ} \mathrm{C}$ for a sample located in the lower crust or upper mantle of the Moon. Thus, the linearity of the data support the hypothesis first proposed by McCallum and Schwartz (2001) that differences between $\mathrm{Rb}-\mathrm{Sr}, \mathrm{Pb}-\mathrm{Pb}$, and $\mathrm{Sm}-\mathrm{Nd}$ ages reflect the cooling history of the sample. From this analysis it is apparent that the Sm-Nd age records a temperature very near that estimated for equilibrium of major mineral phases (Figure 5). In fact, cooling the sample from this temperature at $850 \pm 50{ }^{\circ} \mathrm{C}$ to the calculated closure temperature of the $\mathrm{Sm}-\mathrm{Nd}$ system at $825^{\circ} \mathrm{C}$ will result in a shift in age of less than $13 \mathrm{Ma}$. 


\subsection{Age relationship between the Mg-suite and FAS}

The age of ferroan noritic anorthosite 60025 was determined to be $4359 \pm 2.4 \mathrm{Ma}$ using the $\mathrm{Pb}-\mathrm{Pb}$ system and $4367 \pm 11 \mathrm{Ma}$ using the ${ }^{147} \mathrm{Sm}^{-}{ }^{143} \mathrm{Nd}$ system by Borg et al. (2011). This is one of the most precisely dated FAS samples and is therefore used to evaluate the temporal and isotopic relationships between 76535 and the FAS. The FAS is composed of a group of anorthositic rocks that have major element and REE systematics that are broadly consistent with crystallization in a single evolving magma (Floss et al., 1998). Nevertheless, the FAS minerals exhibit a range trace element abundances and systematics indicative of complex petrogenetic histories that potentially involve crystallization accompanied by infiltration and contamination by more evolved magmas (Floss et al., 1998; James et al., 1991). Thus, although the high Ca content of plagioclase and low $\mathrm{Mg}$ content in mafic minerals suggests an affinity to crystallization products of a punitive lunar magma ocean, these samples need not necessarily represent flotation cumulates of a magma ocean and could instead be produced by some version of serial magmatism. Nevertheless, ages determined on FAS samples provide the only temporal constrains on anorthositic magmatism in the lunar crust and therefore form a basis for age comparisons between various lunar crustal lithologies.

The closure temperatures for $\mathrm{Sm}-\mathrm{Nd}$ and $\mathrm{Pb}-\mathrm{Pb}$ in 60025 have been calculated using the cooling rate estimated for this sample of $18{ }^{\circ} \mathrm{C} / \mathrm{Ma}$ by McCallum and O'Brien (1996) and the Arrhenius relations discussed above. The Sm-Nd system is calculated to close at $870 \pm 14{ }^{\circ} \mathrm{C}$ in plagioclase and $851 \pm 61{ }^{\circ} \mathrm{C}$ in orthopyroxene, whereas the $\mathrm{Pb}-\mathrm{Pb}$ in orthopyroxene is calculated to close at $835 \pm 58{ }^{\circ} \mathrm{C}$. When plotted on Figure 5, it is apparent that sample 60025 does not fall on the trajectory defined by the 76535 age determinations. This observation, however, does not necessarily mean that these rocks formed at different times because the measured ages are unlikely to directly record the time when the rocks solidified. This stems from the fact that these rocks cooled slowly in 
the interior of the Moon so that the closure temperatures of the isotopic systems are substantially below the solidus temperatures.

The age of solidification can be constrained using ages determined on individual rocks along with estimates of their solidus temperatures and cooling rates. The solidus temperature for 76535 is calculated from the bulk composition of the parental Mg-suite magma (Longhi et al., 2010) using the pMELTS algorithm (Ghiroso et al., 2002) at approximately $50 \mathrm{~km}$ depth (McCallun et al., 2006) and is found to be 1100 to $1150{ }^{\circ} \mathrm{C}$. This temperature is close to the eutectic in the end-member ternary system Fo-An- $\mathrm{SiO}_{2}$ which is $1220^{\circ} \mathrm{C}$. The age when 76535 was at its solidus temperature is calculated to be $4384 \pm 24 \mathrm{Ma}$ assuming a solidus temperature of $1125{ }^{\circ} \mathrm{C}$ and a cooling rate of 3.9 ${ }^{\circ} \mathrm{C} / \mathrm{Ma}$ (Figure 5). The errors reflect uncertainty in solidus temperatures and isochron age determinations. The age when ferroan noritic anorthosite 60025 was at its solidus temperature can also be estimated. Using its solidus temperature of $1100-1200{ }^{\circ} \mathrm{C}$ (Longhi and Ashwal, 1985), the $4367 \mathrm{Ma}$ Sm-Nd age (that records the closure of this isotopic system at a temperature of $870{ }^{\circ} \mathrm{C}$ ), and the $18^{\circ} \mathrm{C} / \mathrm{Ma}$ cooling rate determined for this sample by McCallum and O'Brien (1996), an age of $4383 \pm 17 \mathrm{Ma}$ is obtained.

The solidus age of 60025 is not resolvable from the solidus age of 76535 at the level of uncertainty associated with these calculations. The results demonstrate that the internal isochron ages reflect the solidus temperatures of the samples to varying degrees. The Rb-Sr "age" of a slowly cooled rock, such as 76535, is corrected for $105 \mathrm{Ma}$ of growth, whereas the Sm-Nd "age" is corrected for $77 \mathrm{Ma}$ of growth. In contrast, the Sm$\mathrm{Nd}$ "age" of more quickly cooled rock, such as 60025, is corrected for only $16 \mathrm{Ma}$ of growth. It is therefore likely that some of the variation of Sm-Nd ages observed in FAS and $\mathrm{Mg}$-suite rocks plotted in Figure 1 could be associated with the cooling rate of individual samples. Although Sm-Nd ages of the slowest cooled rocks, such as 76535 , are required to be corrected for up to $\sim 80 \mathrm{Ma}$ to account for subsolidus diffusion associated with slow cooling, this mechanism does not appear to be responsible for the young ages recorded in some FAS samples (Borg et al., 1999, 2011; Norman et al., 
2003). This stems from the fact that 60025 cooled fairly rapidly at $\sim 18{ }^{\circ} \mathrm{C} / \mathrm{Ma}$ (McCallum and O'Brien, 1996) and yet has a relatively young Sm-Nd age of $4367 \pm 11$ Ma (Borg et al., 2011). Nor is slow cooling likely to be responsible for the overlap of ages determined for Mg-suite rocks and FAS rocks, despite the fact that samples from both suites of rocks are likely to have cooled at variable rates. Furthermore, if the temporal relationship between 60025 and 76535 is characteristic of FAS and Mg-suite rocks then these suites of rocks are contemporaneous within the present level of uncertainty.

If FAS magmatism is related to solidification of the lunar magma ocean (e.g., Wood et al., 1970), then Mg-suite magmatism must be temporally related to the solidification process as well. One possible explanation for near contemporaneous FAS and $\mathrm{Mg}$-suite magmatism around $4385 \mathrm{Ma}$ in the context of differentiation in a magma ocean is if FAS represent products of LMO solidification and Mg-suite magmas were produced close enough in time so that the chronometers do not have the resolution to distinguish primordial solidification (FAS) from secondary magmatism (Mg-suite). However, the production of Mg-suite magmas near the time of primordial solidification of the magma ocean is contradictory to traditional lunar magma ocean model which predicts that FAS magmatism should predate magmatism associated with the $\mathrm{Mg}$-suite (e.g., Longhi, 1981; Shirley, 1983; Shearer et al., 2006). Therefore a second possibility is that FAS are not be produced by magma ocean solidification so that nearly contemporaneous FAS and Mg-suite magmatism simply reflects near contemporaneous melting of different magmatic sources. Several models have been proposed to account for the production of FAS rocks in the absence of a magma ocean. These serial magmatism models suggest that FAS rocks are produced by remobilization of anorthosite to the surface associated with impacts (Smith, 1981), by remobilization of pre-existing anorthosite in layered intrusions (Wetherill, 1975; Walker, 1983), and by late melting of plagioclase-rich lunar mantle (Longhi, 2003). The two possibilities can, in principle, be distinguished using the $\mathrm{Sr}$ and $\mathrm{Nd}$ isotopic compositions of the samples. If the FAS represents magma ocean cumulates that formed nearly contemporaneously with $\mathrm{Mg}$-suite magmas, both sample types should have very similar initial $\mathrm{Sr}$ and $\mathrm{Nd}$ isotopic 
compositions that reflect evolution in a previously undifferentiated reservoir. On the other hand, if the samples represent magmas produced by melting and secondary mobilization of substantially older cumulates they are expected to have different initial $\mathrm{Sr}$ and $\mathrm{Nd}$ isotopic compositions that reflect growth in previously differentiated reservoirs. It is important to note, however, that $\mathrm{Sr}$ and $\mathrm{Nd}$ isotopic compositions of FAS and $\mathrm{Mg}$ suite samples would be similar, and not significantly different from the isotopic composition of the bulk Moon, if they were produced by melting of newly formed LMO cumulates.

\section{3 $\mathrm{Sr}$ and $\mathrm{Nd}$ isotopic evolution of Mg-suite and FAS source regions}

The initial ${ }^{87} \mathrm{Sr} /{ }^{86} \mathrm{Sr}$ and ${ }^{143} \mathrm{Nd} /{ }^{144} \mathrm{Nd}$ ratios determined from the 76535 isochrons (Figures 3 and 4) record the isotopic composition of the rock at 4279 and $4307 \mathrm{Ma}$, respectively. These isochrons yield initial ${ }^{87} \mathrm{Sr} /{ }^{86} \mathrm{Sr}=0.699100 \pm 0.00009$, initial $\varepsilon^{143} \mathrm{Nd}$ value $=-0.16 \pm 0.15$, and an initial $\varepsilon^{142} \mathrm{Nd}$ value (relative to present-day ${ }^{142} \mathrm{Nd} /{ }^{144} \mathrm{Nd}=$ 1.141839 ) of $-0.60 \pm 0.12$. Although the initial Sr isotopic composition of 60025 at the $\mathrm{Rb}$-Sr equilibrium temperature cannot be calculated in the absence of a $\mathrm{Rb}-\mathrm{Sr}$ isochron, the initial $\mathrm{Nd}$ isotopic composition determined for 60025 from Sm-Nd isochrons by Borg et al. (2011) are $\varepsilon^{143} \mathrm{Nd}$ value of $-0.24 \pm 0.09$ and an $\varepsilon^{142} \mathrm{Nd}$ value of $-0.67 \pm 0.15$. The $\mathrm{Nd}$ isotopic compositions of both rocks are in excellent agreement, suggesting growth in minimally differentiated reservoirs. For example, single-stage growth models demonstrate that the sources of 76535 and 60025 range from 0.193 to 0.198 and closely approximate the ${ }^{147} \mathrm{Sm} /{ }^{144} \mathrm{Nd}$ value determined for chondritic meteorites (Figure 6). In these calculations, the bulk Moon is assumed to have present-day chondritic Sm-Nd isotopic composition of ${ }^{147} \mathrm{Sm} /{ }^{144} \mathrm{Nd}=0.1967$ and ${ }^{143} \mathrm{Nd} /{ }^{144} \mathrm{Nd}=0.512638$ (Jacobsen and Wasserburg, 1980). The ${ }^{147} \mathrm{Sm} /{ }^{144} \mathrm{Nd}$ ratio of the source region does not change if the bulk Moon is assumed to have different ${ }^{147} \mathrm{Sm} /{ }^{144} \mathrm{Nd}$ and ${ }^{143} \mathrm{Nd} /{ }^{144} \mathrm{Nd}$ ratios (e.g., Bouvier et al., 2008). The ${ }^{87} \mathrm{Rb} /{ }^{86} \mathrm{Sr}$ ratio of the 76535 source is similarly calculated assuming the bulk Moon had an ${ }^{87} \mathrm{Sr} /{ }^{86} \mathrm{Sr}$ ratio of 0.698978 at $4567 \mathrm{Ma}$ (Hans et al., 2013; Gray et al., 1973; Podosek et al., 1991; Marks et al., 2014a). In this case the source of 76535 is 
calculated to have an ${ }^{87} \mathrm{Rb} /{ }^{86} \mathrm{Sr}$ ratio of $0.030 \pm 0.02$ that closely matches values of 0.016 to 0.027 estimated for the bulk Moon (Wanke et al., 1977; Taylor 1982).

Although the initial $\mathrm{Sr}$ and $\mathrm{Nd}$ isotopic compositions of 76535 and 60025 support the hypothesis that they solidified relatively late in solar system history from a previously undifferentiated reservoir, it is important to note that the measured ages and initial $\mathrm{Sr}$ and $\mathrm{Nd}$ isotopic compositions record the closure of the isotopic systems to diffusion and do not directly record the age or isotopic composition of the rock when it solidified. In order to determine the $\mathrm{Sr}$ and $\mathrm{Nd}$ isotopic compositions of 76535 when the rock first passed below its solidus temperature from the initial $\mathrm{Sr}$ and $\mathrm{Nd}$ isotopic compositions measured by the isochrons (Figures 3-4), corrections for radiogenic growth in the rock occurring between the solidus temperature of $1125{ }^{\circ} \mathrm{C}$ and the closure temperature for $\mathrm{Sm}-\mathrm{Nd}$ of $825{ }^{\circ} \mathrm{C}$ must be made. The ${ }^{87} \mathrm{Rb} /{ }^{86} \mathrm{Sr}$ and ${ }^{147} \mathrm{Sm} /{ }^{144} \mathrm{Nd}$ ratios of the bulk rock were measured by Haskin et al. (1974) on a large $\sim 0.5 \mathrm{~g}$ split and found to be 0.0061 and 0.161 , respectively. Assuming these values are representative of this coarse-grained rock, the $\mathrm{Sr}$ and $\mathrm{Nd}$ isotopic compositions of 76535 at its solidus temperature are calculated to be ${ }^{87} \mathrm{Sr} /{ }^{86} \mathrm{Sr}=0.699091 \pm 0.000010, \varepsilon^{143} \mathrm{Nd}=0.12 \pm 0.22$, and $\varepsilon^{142} \mathrm{Nd}=-$ $0.88 \pm 0.19$. There is a slight expansion of uncertainty associated with the isotopic values of the rocks at their solidus temperatures compared to the equilibrium values determined from the isochrons as a result of propagation of errors in the calculated solidus temperatures.

The $\mathrm{Nd}$ isotopic composition of 60025 at its solidus temperature is calculated from the Sm-Nd isochrons (Borg et al. 2011), assuming a solidus temperature of $1150{ }^{\circ} \mathrm{C}$ (Longhi and Ashwal, 1985), the cooling rate of $18^{\circ} \mathrm{C} / \mathrm{Ma}$ determined by McCallum and O'Brien (1996), and the closure temperature of Sm-Nd in 60025 of $870{ }^{\circ} \mathrm{C}$. The initial $\mathrm{Nd}$ isotopic compositions derived from the isochrons are corrected using the average bulk rock ${ }^{147} \mathrm{Sm} /{ }^{144} \mathrm{Nd}$ ratio of 0.132 (Haskin et al., 1973) and determined to be $\varepsilon^{143} \mathrm{Nd}=-0.10$ \pm 0.09 and $\varepsilon^{142} \mathrm{Nd}=-0.68 \pm 0.15$ (relative to present-day ${ }^{142} \mathrm{Nd} /{ }^{144} \mathrm{Nd}=1.141839$ ). The ${ }^{87} \mathrm{Sr} /{ }^{86} \mathrm{Sr}$ of 60025 at its solidus temperature is calculated to be $0.699062 \pm 0.000014$ from 
the ${ }^{87} \mathrm{Rb} /{ }^{86} \mathrm{Sr}$ and ${ }^{87} \mathrm{Sr} /{ }^{86} \mathrm{Sr}$ ratios of 0.0039 and $0.699087 \pm 0.000014$ measured on a plagioclase fraction by Borg et al. (2011).

The isotopic compositions of 76535 calculated at its solidus can be directly compared to those of 60025 at its solidus because the estimated cooling rates of both of these samples suggest they were at their respective solidi contemporaneously near 4384 Ma. The $\varepsilon^{143} \mathrm{Nd}$ and $\varepsilon^{142} \mathrm{Nd}$ values of both 76535 and 60025 calculated at their solidus temperatures at $4383 \pm 24 \mathrm{Ma}$ and $4384 \pm 17 \mathrm{Ma}$ are within uncertainty. Single-stage growth calculations (Figure 6A-B) demonstrate the relationship between their age and isotopic compositions. The isotopic compositions and ages of the rocks are plotted for both the closure temperatures of Sm-Nd (circles) and for the solidus temperatures (squares). Single stage ${ }^{147} \mathrm{Sm}-{ }^{143} \mathrm{Nd}$ evolution models demonstrate that the $\varepsilon^{143} \mathrm{Nd}$ value of 76535 at its solidus temperature is consistent with derivation from a source with a ${ }^{147} \mathrm{Sm} /{ }^{144} \mathrm{Nd}$ ratio of $0.202 \pm 0.080$, whereas the $\varepsilon^{143} \mathrm{Nd}$ value of 60025 indicates that it is derived from a source with a ${ }^{147} \mathrm{Sm} /{ }^{144} \mathrm{Nd}$ ratio of $0.193 \pm 0.037$. Similar single-stage growth calculations for the ${ }^{146} \mathrm{Sm}^{142} \mathrm{Nd}$ isotopic system demonstrate that the source of 76535 has a ${ }^{147} \mathrm{Sm} /{ }^{144} \mathrm{Nd}$ ratio of $0.194 \pm 0.017$, and that the 60025 source has a ${ }^{147} \mathrm{Sm} /{ }^{144} \mathrm{Nd}$ of $0.212 \pm 0.014$. This calculation assumes that the ${ }^{142} \mathrm{Nd} /{ }^{144} \mathrm{Nd}$ ratio of the bulk Moon is the same as bulk Earth and is defined as 1.141839 by replicate analyses of the LaJolla and JNdi Nd standards (Table 2). This assumption is supported by the recent observation of Burkhardt et al. (2016) that differences in ${ }^{142} \mathrm{Nd}$ between Earth and chondrites reflect nucleosynthetic processes so that Earth is expected to have a different ${ }^{142} \mathrm{Nd} /{ }^{144} \mathrm{Nd}$ ratio then chondrites. These calculations demonstrate that the Sm-Nd isotopic systematics of 76535 and 60025 are similar and not clearly different from growth models for undifferentiated bodies based on ${ }^{147} \mathrm{Sm} /{ }^{144} \mathrm{Nd}$ and ${ }^{143} \mathrm{Nd} /{ }^{144} \mathrm{Nd}$ ratios of chondritic meteorites. Thus, the $\mathrm{Sm}-\mathrm{Nd}$ isotopic systematics of these rocks indicates that they cannot be derived from source regions that formed early in the history of the solar system. 
The Sr isotopic composition of 60025 at its solidus suggests its source had an ${ }^{87} \mathrm{Rb} /{ }^{86} \mathrm{Sr}$ ratio that was similar to compositions estimated for the bulk Moon as well. A single stage model of $\mathrm{Sr}$ growth indicates that the ${ }^{87} \mathrm{Sr} /{ }^{87} \mathrm{Sr}$ of 60025 is consistent with growth in a source region with ${ }^{87} \mathrm{Rb} /{ }^{86} \mathrm{Sr}$ of $0.033 \pm 0.005$ that is similar to estimates for the bulk Moon ranging from 0.016 to 0.027 (Wanke et al., 1977; Taylor 1982). However, unlike the 60025, the Sr isotopic systematics of 76535 are not consistent with growth in an undifferentiated reservoir from 4567 to 4384 Ma. Single stage growth models demonstrate that in order to reproduce the ${ }^{87} \mathrm{Sr} /{ }^{86} \mathrm{Sr}$ of 76535 of $0.699091 \pm 0.000010$ at its solidus from an initial ${ }^{87} \mathrm{Sr} /{ }^{86} \mathrm{Sr}$ ratio of 0.698978 (Hans et al., 2013; Gray et al., 1973; Podosek et al., 1991; Marks et al., 2014a), the reservoir must have a ${ }^{87} \mathrm{Rb} /{ }^{86} \mathrm{Sr}$ of $0.044 \pm$ 0.004. This value is substantially elevated from that estimated of the bulk Moon of 0.016 to 0.027 , but lower than the value estimated for bulk Earth of 0.087 (Anders, 1977; Wanke et al., 1977; Taylor 1982). This suggests that 76535, and probably all other Mgsuite rocks, were produced by melting or re-equilibrium of previously formed cumulates and cannot be differentiation products of the LMO.

Model ages for the formation of the 76535 source cannot be accurately calculated from the $\mathrm{Rb}-\mathrm{Sr}$ data because the ${ }^{87} \mathrm{Rb} /{ }^{86} \mathrm{Sr}$ ratio of the source is not known. For example, if the source region had an ${ }^{87} \mathrm{Rb} /{ }^{86} \mathrm{Sr}$ ratio similar to the bulk rock value, the source would need to form significantly after 76535 formed. On the other hand, if the ${ }^{87} \mathrm{Rb} /{ }^{86} \mathrm{Sr}$ ratio of the source was similar to ur-KREEP value of 0.318 (Warren, 1988) an age of $4401 \pm 32$ $\mathrm{Ma}$ is implied. The uncertainty reflects the propagation of errors in the solidus cooling age, the ${ }^{87} \mathrm{Sr} /{ }^{86} \mathrm{Sr}$ ratio of the 76535 source region, and the ${ }^{87} \mathrm{Rb} /{ }^{86} \mathrm{Sr}$ of the bulk Moon. The pronounced ur-KREEP incompatible element signatures observed in Mg-suite rocks (e.g., Shearer et al., 2006) suggests ur-KREEP is a reasonable approximation of the ${ }^{87} \mathrm{Rb} /{ }^{86} \mathrm{Sr}$ of the 76535 source region and that the age of formation of the 76535 source is probably not significantly older than $\sim 400 \mathrm{Ma}$.

\subsection{Petrogenesis Mg-suite and FAS}


The chronology and Sr and Nd isotope systematics of FAS sample 60025 and Mg-suite sample 76535 are consistent with evolution in both a LMO and by serial magmatism. If FAS represent primordial solidification products of the LMO, then the Moon must have solidified relatively late in solar system history. The observation the age of the 76535 source is likely to be slightly older than the solidus age of 60025 , implies that the Moon solidified over tens of millions of years allowing some FAS samples to be younger than some Mg-suite source regions. Ur-KREEP model ages provide some support for relatively late solidification age of the Moon. For example, UrKREEP Sm-Nd model ages were calculated by Carlson and Lugmair (1979), Nyquist and Shih (1992), and Edmunson et al. (2009) to be $4.36 \pm 0.06 \mathrm{Ga}, 4.42 \pm 0.07 \mathrm{Ga}$ and $4.49 \pm$ $0.06 \mathrm{Ga}$, respectively. A review of the literature led Borg et al. (2015) and Gaffney and Borg (2014) to propose a more precise Sm-Nd ur-KREEP model age of $4389 \pm 45 \mathrm{Ma}$ that overlaps the age of $4401 \pm 32$ defined by the formation of the 76535 source. Finally, it should be noted that the near chondritic Nd isotopic composition of 60025 at its solidus is consistent with formation of the sample in the context of plagioclase accumulation in the LMO.

On the other hand, if FAS sample 60025 represents a product of serial magmatism, then contemporaneous solidification of FAS and $\mathrm{Mg}$-suite samples is not unexpected making this interpretation somewhat more appealing. The $\mathrm{Sr}$ and $\mathrm{Nd}$ isotopic systematics of 76535 and 60025 imply that both the FAS and $\mathrm{Mg}$-suite must be derived from source regions that did not form significantly before the rocks themselves. This is based on the observation that $\mathrm{Rb}-\mathrm{Sr}$ and $\mathrm{Sm}-\mathrm{Nd}$ isotopic systematics of these lunar rocks are very similar to each other and to estimates for the bulk Moon. This requires the sources of these materials to be either minimally differentiated from the composition of the bulk Moon or to have formed at about the same time as the samples. Because major and trace element compositions of the source of these rocks are different from one another and from estimates for the bulk Moon, it seems likely that theyformed just prior to the ages defined by the samples. The relatively young ur-KREEP model age is also consistent with this model of lunar evolution. Source regions forming before the maximum age of ur-KREEP $(4.43 \mathrm{Ga})$ are likely to have isotopic systematics that deviate 
measurably from the roughly chondritic values measured for 76535 and 60025 . Thus, the age of primordial differentiation of the Moon is probably not significantly older than about $4.43 \mathrm{Ga}$, the oldest source age determined here, regardless of whether lunar differentiation occurred in a magma ocean or by serial magmatism.

\section{Conclusion}

Ages of troctolite 76535 have been determined by ${ }^{147} \mathrm{Sm}-{ }^{143} \mathrm{Nd},{ }^{146} \mathrm{Sm}-{ }^{142} \mathrm{Nd}$, and ${ }^{87} \mathrm{Rb}-{ }^{86} \mathrm{Sr}$ be $4307 \pm 11 \mathrm{Ma}, 4299{ }^{+29 /}{ }_{-35} \mathrm{Ma}$, and $4279 \pm 52 \mathrm{Ma}$, respectively. A cooling rate of $\sim 4{ }^{\circ} \mathrm{C} / \mathrm{Ma}$ is estimated for 76535 from these ages, as well as $\mathrm{Ar}-\mathrm{Ar}$ and $\mathrm{Pb}-\mathrm{Pb}$ ages reported in the literature, and closure temperatures estimated for these isotopic systems. There is good agreement between the cooling rate estimated using the four chronometers and the cooling rate estimated from the textures and mineral chemistry of the sample of 1-5 ${ }^{\circ} \mathrm{C} / \mathrm{Ma}$ estimated by Nord (1976) and Stewart (1975). Using this cooling rate the age when 76535 was at its solidus temperature of $1125{ }^{\circ} \mathrm{C}$ is estimated to be $4384 \pm 24 \mathrm{Ma}$ and is in good agreement with the age of $4383 \pm 17$ Ma estimated when ferroan noritic anorthosite 60025 was at its solidus temperature assuming a cooling rate of $18{ }^{\circ} \mathrm{C} / \mathrm{Ma}$ determined by McCallum and O'Brien (1996). This implies that FAS and Mg-suite magmatism was occurring nearly simultaneously on the Moon. The $\mathrm{Nd}$ isotopic compositions of 76535 and 60025 are in good agreement and consistent with derivation of these rocks from sources with similar ${ }^{147} \mathrm{Sm} /{ }^{144} \mathrm{Nd}$ ratios that are minimally different from estimates of the bulk planet based on analysis of chondritic meteorites. The ${ }^{87} \mathrm{Rb} /{ }^{86} \mathrm{Sr}$ ratio of the source of 76535 , however, is elevated above estimates for the bulk Moon, suggesting the 76535 source underwent a small amount of fractionation prior to the formation of 76535. These observations are consistent with differentiation of the Moon occurring relatively late in solar system history and are independent of the mode of differentiation. Perhaps the best estimate for the age of differentiation is based on model ages of ur-KREEP of $4389 \pm 45 \mathrm{Ma}$ and the 76535 source region of $4401 \pm 32 \mathrm{Ma}$, implying a maximum solidification age for at least part of the Moon of $\sim 4.43 \mathrm{Ga}$. 


\section{ACKNOWLEDGEMENTS}

We are grateful to D. A. Papanastassiou and G. J. Wasserburg for donating the mineral separates of sample of 76535 used in this investigation. Detailed characterization of the original mineral fractions greatly facilitated interpretation of the isotopic data. Discussions with D. A. P., Ian Hutcheon, and Chip Shearer were also extremely helpful. This work was performed under the auspices of the U.S. Department of Energy by Lawrence Livermore National Laboratory under Contract DE-AC52-07NA27344. LLNLJRNL-660422. This work was supported by NASA Cosmochemistry grants NNH12AT84I to L.E.B and NNH13AW501 to A. M. G.

\section{References}

Alibert C., Norman M. D., McCulloch M. T. (1994) An ancient age for a ferroan anorthosite clast from lunar breccia 67016. Geochim. Cosmochim. Acta 58, 29212926.

Anders E. (1977) Chemical compositions of the Moon, Earth, and eucrite parent body. Phil. Trans. Roy. Soc. A285, 23-40.

Anders E. and Grevesse N. (1989) Abundances of the elements: Meteoritic and solar. Geochim. Cosmochim. Acta 53, 197-214.

Binder A. B. (1986) The initial thermal state of the Moon. In Origin of the Moon. pp425434, W. K. Hartmann, R. J. Phillips, G. J. Taylor (eds.) Edwards Bros. Houston.

Borg L. E., Brennecka G. A., and Symes S. J. K. (2016) Accretion timescale and impact history of Mars deduced from the isotopic systematics of martian meteorites, Geochim et Cosmochim Acta. 175, 150-167.

Borg L. E., Gaffney A. M., and Shearer C. K. (2015) A review of lunar chronology revealing a preponderance of 4.34-4.37 Ga ages. Meteor. Planet. Sci. 50, 715-732. 
Borg L. E., Connelly J. N., Boyet, M., and Carlson R. W. (2011) Evidence that the Moon is either young or did not have a global magma ocean. Nature, 477, 70-72.

Borg L. E., Norman M., Nyquist L. E., Bogard D., Snyder G. A., Taylor L. A., and Lindstrom M. (1999) Isotopic studies of ferroan anorthosite 62236: A young lunar crustal rock from a light rare-earth element-depleted source. Geochimica et Cosmochim. Acta 63, 2679-2691.

Boss A. P. and Peale S. J. (1986) Dynamical constraints on the origin of the Moon. In Origin of the Moon. pp. 59-102, W. K. Hartmann, R. J. Phillips, G. J. Taylor (eds.) Edwards Bros. Houston.

Bouvier A., Vervoort J. D., and Patchett J. (2008) The Lu-Hf and Sm-Nd isotopic composition of CHUR: Constraints from unequilibrated chondrites and implications for the bulk composition of terrestrial planets. Earth Planet. Sci. Lett. 273, 48-57.

Boyet M. and Carlson R. W. (2005) ${ }^{142} \mathrm{Nd}$ evidence for early (>4.53) global differentiation of the silicate Earth. Science, 309, 576-581.

Boyet M. and Carlson R. W. (2007) A highly depleted moon or a non-magma ocean origin for the lunar crust? Earth Planet. Sci. Lett. 262, 505-516.

Boyet M., Carlson R. W., and Horan M. (2010) Old Sm-Nd ages for cumulate eucrites and redetermination of the solar system initial ${ }^{146} \mathrm{Sm} /{ }^{144} \mathrm{Sm}$ ratio. Earth Planet. Sci. Lett. 291, 172-181.

Burkhardt C., Borg L. E., Brennecka G. A., Shollenberger Q. R., Dauphas N., and Kleine T. (2016) A nucleosynthetic origin of the Earth's anomalous ${ }^{142} \mathrm{Nd}$ composition. Nature.537, 394-398

Carlson R. W. and Lugmair G. W. (1979) Sm/Nd constraints on early lunar differentiation and the evolution of KREEP. Earth Planet. Sci. Lett. 45, 123-132.

Carlson R. W. and Lugmair G. W. (1981a) Sm-Nd age of lherzolite 67667: implications for the processes involved in lunar crustal formation. Earth Planet. Sci. Lett. 56, 1-8.

Carlson R. W. and Lugmair G. W. (1981b) Time and duration of lunar crust formation. Earth Planet. Sci. Lett. 52, 227-238. 
Carlson R. W. and Lugmair G. W. (1988) The age of ferroan anorthosite 60025: Oldest crust on a young Moon? Earth Planet. Sci. Lett. 90, 119-130.

Carlson R. W., Borg L. E., Gaffney A. M., and Boyet M. (2014) Rb-Sr, Sm-Nd, and LuHf isotopic systematics of lunar Mg-suite: the age of the lunar crust and its relation to the time of Moon formation. Trans Roy. Soc. A 372, 20130246.

Cassata W. S. and Renne P. R. (2013) Systematic variations of argon diffusion in feldspars and implications for thermochronology. Geochim. et Cosmochim. Acta 112, 251-287.

Cassata and Borg (2015) New constraints on the timing of basin-forming impact events from excavated crustal rocks. SSERVI Exploration Science Forum July 21-23, 2015 Moffit Field CA (abstract).

Cherniak, D.J. (1995) Diffusion of lead in plagioclase and K-feldspar: an investigation using Rutherford Backscattering and resonant nuclear reaction analysis. Contrib. Mineral. Petrol. 120, 358-371.

Cherniak D. J. (2003) REE diffusion in feldspar. Chem. Geo. 193, 25-41.

Cherniak, D.J. and Watson, E.B. (1994) A study of strontium diffusion in plagioclase using Rutherford Backscattering spectroscopy. Geochim. Cosmochim. Acta 58, 51795190.

Cherniak, D.J and Liang Y. (2007) Rare earth element diffusion in natural enstatite. Geochim. Cosmochim. Acta 71, 1324-1340.

Compston W., Foster J. J., and Gray C. M. (1975) Rb-Sr ages of clasts within Boulder 1, Station 2, Apollo 17. The Moon, 14, 445-462.

Connelly J. N., Amelin Y., Krot A. N, and Bizzarro M. (2008) Chronology of the Solar System's oldest solids. Astrophys. J. Lett. 675, L121-L124.

Connelly J. N. and Bizzarro M. (2009) Pb-Pb dating of chondrules from CV chondrites by progressive dissolution. Chem. Geol. 259, 143-151.

Dodson M. H (1973) Closure temperature in cooling geochronological and petrological systems. Contrib. Mineral. Petrol. 40, 259-264. 
Dodson M. H (1986) Closure profiles in cooling systems, in P.F. Dennis, R. Freer (Eds.) Kinetics and transport in silicate and oxide systems. Materials Science Forum. 7, Min. Soc. Great Britain, 1986, pp. 145-154.

Dymek R.F., Albee A. L., and Chodos A. A. (1975) Comparative petrology of lunar cumulate rocks of possible primary origin: Dunite 74215 , troctolite 76535 , norite 78235, and anorthosite 62237. Proc. $6^{\text {th }}$ Lunar Conf. 301-341.

Edmunson J., Nyquist L. E., and Borg L. E. (2007) Sm-Nd isotopic systematics of troctolite 76335. 38 ${ }^{\text {th }}$ Lunar Planet. Sci. Conf. (abstr. \# 1962).

Edmunson J., Borg L. E., Nyquist L. E., and Asmeron Y. (2009) A combined Sm-Nd, $\mathrm{Rb}-\mathrm{Sr}$, and $\mathrm{U}-\mathrm{Pb}$ isotopic study of Mg-suite norite 78238: Further evidence for early differentiation of the Moon. Geochim. et Cosmochim. Acta 73, 514-527.

Elardo S. M., McCubbibn F. M., and Shearer C. S. (2012) Chromite symplectites in Mgsuite troctolite 76535 as evidence for infiltration metasomatism of a lunar layered intrusion. Geochim Cosmochim Acta 87, 154-177.

Floss C., James O. B., McGee J. J., and Crozaz G. (1998) Lunar ferroan anorthosite petrogenesis: Clues from trace element distributions in FAN subgroups. Geochim Cosmochim Acta 62, 1255-1283.

Gaffney A. M., and Borg L. E. (2014) A young solidification age for the lunar magma ocean Geochim.Cosmochim. Acta 140, 227-240.

Gaffney A. M., Borg L. E., Shearer C. K., and Burger P. V. (2015) Chronology of 15445 norite clast B and implications for $\mathrm{Mg}$-suite magmatism $46^{\text {th }}$ Lunar Planet. Sci. Conf. (abstr. \# 1443).

Ganguly, J. and Tirone, M. (1999) Diffusion closure temperature abd age of a mineral with arbitrary extent of diffusion: theoretical formulation and applications. Earth Planet. Sci. Lett. 170, 131-140.

Gray C. M., Papanastassiou D. A., and Wasserburg G. J. (1973) Identification of early condensates from the solar nebula Icarus, 20, 213-239. 
Ghiorso, M. S., Hirschmann, M. M., Reiners, P. W., and Kress, V. C. III (2002) The pMELTS: An revision of MELTS aimed at improving calculation of phase relations and major element partitioning involved in partial melting of the mantle at pressures up to $3 \mathrm{GPa}$. Geochemistry, Geophysics, Geosystems 3, 10.1029/2001GC000217

Gooley R., Brett R., Warner J., and Smyth J. R. (1974) A lunar rock of deep crustal; origin: Sample 76535. Geochim. Cosmochim. Acta 38, 1329-1339.

Hans U., Kleine T., and Bourdon B. (2013) Rb-Sr chronology of volatile depletion in differentiated protoplanets: BABA, ADOR and ALL revisited. Earth Planet. Sci. Lett. 374, 204-214.

Hartmann W. K. and Davis D. R. (1975) Satellite-sized planetismals and lunar origin. Icarus 24, 504-515.

Haskin L. A. Helmke P. A., Blanchard D. P., Jacobs J. W., and Telander K. (1973) Major and trace element abundances in samples from the lunar highlands. . Proc. $4^{\text {th }}$ Lunar Conf. 1275-1296.

Haskin L. A., Shih C. -Y., Basnal B. M., Rhodes J. M., Wiesmann H., and Nyquist L. E. (1974) Chemical evidence for the origin of 76535 as a cumulate. Proc. $5^{\text {th }}$ Lunar Conf. 1213-1225.

Husain L. and Schaeffer O.A. (1975) Lunar evolution: The first 600 million years.

Geophys. Res. Lett. 2, 29-32.James O. B. (1980) Rocks of the early lunar crust. Proc. $11^{\text {th }}$ Lunar Planet. Sci. Conf. 365-393.

James O. B., Lindstrom M. M., and McGee J. J. (1991) Lunar ferroan anorthosite 60025: Petrology and chemistry of mafic lithologies. Proc. Lunar Planet. Sci. 21, 63-87.

Jacobsen S. B. and Wasserburg G. J. (1980) Sm-Nd isotopic evolution of chondrites. Earth Planet. Sci. Lett. 50, 139-156.

Kinoshita N., Paul M., Kashiv Y., Collon P., Deibel C. M., DiGiovine B., Greene J. P., Henderson D. J., Jiang C. L., Marley S. T., Nakanishi T., Pardo R. C., Rehm K. E., Robertson D., Scott R., Schmitt C., Tang X. D., Vondrasek R., Yokoyama A., (2012) A Shorter ${ }^{146} \mathrm{Sm}$ Half-Life Measured and Implications for ${ }^{146} \mathrm{Sm}-{ }^{142} \mathrm{Nd}$ Chronology in the Solar System. Science, 335, 1614-1617. 
Longhi, J. (1981) Preliminary modeling of high pressure partial melting; Implications for early lunar differentiation, Proc. Lunar Planet. Sci.I2B, 1001-1018.

Longhi J. (2003) A new view of ferroan anorthosites: Postmagma ocean petrogenesis. Jour. Geophysi. Res. 108, 5083-5098.

Longhi, J., Durand, S.R., and Walker, D. (2010) The pattern of Ni and Co abundances in lunar olivine. GCA 74, 784-798.

Longhi J. and Ashwal L. D. (1985) Two-stage models for lunar and terrestrial anorthosites: Petrogenesis without a magma ocean. J. Geophys. Res. 90, C571-C584.

Ludwig K. (1991) ISOPLOT: A plotting and regressions program for radiogenic isotope data, version 2.53. Open-file Report 91-0445. U. S. Geological Survey.

Lugmair G. W., Marti K., Kurtz J. P., and Scheinin N. B. (1976) History and genesis of lunar troctolite 76535. Proc. 7th Lunar Planet. Sci Conf., 2009-2033.

Marks N. E., Borg L. E., Hutcheon I. D., Jacobsen B., and Clayton R. N. (2014a) Samarium-neodymium chronology and rubidium-strontium systematics of an Allende calcium-aluminum-rich inclusion with implications for the ${ }^{146} \mathrm{Sm}$ half-life. Earth Planet. Sci. Lett. 405, 15-24.

Marks N. E., Borg L. E., Gaffney A. M., Shearer C. K., and Burger P. V. (2014b) Additional evidence for ferroan anorthosite magmatism on the Moon from Sm-Nd isotopic measurements of 60016 clast 3A. $45^{\text {th }}$ Lunar Planet. Sci. Conf. (abstr. \# 1129).

McCallum I. S and O'Brien H. F. (1996) Stratigraphy of the lunar highland crust: Depth of burial of lunar samples from cooling rate studies. Am. Min. 81, 1166-1175.

McCallum I. S. and Schwartz J. M. (2001) Lunar Mg suite: Thermobarometry and petrogenisis of parent magmas. Jour. Geophys. Res. 106, 27969-27983.

McCallum I. S., Domeneghetti M. C., Schwartz J. M., Mullen E. K., Zema M., Cámara F. McCammon C, and Ganguly J. (2006) Cooling history of lunar Mg-suite gabbronorite 76255, troctolite 76535, and Stillwater pyroxenite SC-936: The record in exsolution and ordering in pyroxenes. Geochim. Et Cosmochim. Acta 70, 6068-6078. 
Nord G. L. (1976) Thermal history deduced from pyroxene precipitation in anorthite. Proc. $8^{\text {th }}$ Lunar Planet. Sci. Conf. 3083-3093.

Norman M. D., and Ryder G. (1980) Geochemical constraints on igneous evolution of the lunar crust. Proc. $11^{\text {th }}$ Lunar Planet. Sci. Conf. 317-331.

Norman M.D., Borg L.E., Nyquist L.E., and Bogard D.D. (2003) Chronology, geochemistry, and petrology of a ferroan noritic anorthosite clast from Descartes breccia 67215: Clues to the age, origin, structure, and impact history of the lunar crust. Meteor. Planet. Sci. 38, 645-661.

Nyquist L. E. and Shih C. -Y. (1992) The isotopic record of lunar volcanism. Geochim. Cosmochim. Acta 56, 2213-2234.

Nyquist L. E., Wiesmann H., Bansal B. M., Shih C. -Y., Keith J. E., and Harper C. L. (1995) ${ }^{146} \mathrm{Sm}-{ }^{142} \mathrm{Nd}$ formation interval for the lunar mantle. Geochim. Cosmochim. Acta 59, 2817-2837.

Nyquist L. E., Bogard D., Yamaguchi A., Shih C. -Y., Karouji Y., Ebihara M., Reese Y., Garrison D., McKay G., and Takeda H. (2006) Feldspathic clasts in Yamato-86032: Remnants of the lunar crust with implications for its formation and impact history. Geochim. et Cosmochim. Acta 70, 5990-6015.

Nyquist L. E., Shih C.-Y., and Reese Y. D. (2012) Redetermination of the Sm-Nd age and initial $\varepsilon_{\mathrm{Nd}}$ of lunar troctolite 76535: Implications for lunar crustal development. $43^{\text {rd }}$ Lunar Planet. Sci. Conf. abstr. \#2416.

Papanastassiou D. A. and Wasserburg G. J. (1975) Rb-Sr study of lunar dunite and evidence for early lunar differentiation. Proc. $6^{\text {th }}$ Lunar Sci. Conf. 1467-1490.

Papanastassiou D. A. and Wasserburg G. J. (1976) Rb-Sr age of troctolite 76535. Proc. $7^{\text {th }}$ Lunar Sci. Conf. 2035-2054.

Papike J. J., Fowler G. W., Shearer C. K., and Layne G. D. (1996) Ion microprobe investigation of plagioclase and orthopyroxene from lunar $\mathrm{Mg}$-suite norites: Implications for calculating parental melt REE concentrations and for assessing postcrystallization REE distribution. Geochim. Cosmochim. Acta 60, 3967-3978. 
Podosek F. A., Zinner E. K., Macpherson G. J., Lundberg L. L., Brannon J. C., and Fahey A. J. (1991) Correlated study of initial ${ }^{87} \mathrm{Sr} /{ }^{86} \mathrm{Sr}$ and Al-Mg isotopic systematics and petrologic properties in a suite of refractory inclusions from the Allende meteorite. Geochim Cosmochim Acta, 55, 1083-1110.

Premo W. R. and Tatsumoto M. (1992) U-Th-Pb, Rb-Sr, and Sm-Nd isotopic systematics of lunar troctolite cumulate 76535: Implications on the age and origin of this early lunar, deep-seated cumulate. Proc. $22^{\text {nd }}$ Lunar Planet. Sci. Conf. 381-397.

Pritchard M. E. and Stevenson D. J. (2000) Thermal implication of lunar origin by giant impact. In Origin of the Earth and Moon. Cannup R. M., Righter K. (eds) Univ. Arizona Press p 179-196.

Rhodes J. M., Rodgers C., Shih C., Bansal B. M., Nyquist L. E., Wiesmann H., and Hubbard N. J. (1974) The relationships between geology and soil chemistry at the Apollo 17 landing site. Proc. $5^{\text {th }}$ Lunar Sci. Conf. 1097-1117.

Shearer C. K., Hess P. C., Wieczorek M. A., Pritchard M. E., Parmentier E. M., Borg L. E., Longhi J., Elkins-Tanton L., Neal C. R., Antonenko I., Canup R. M., Halliday A. N., Grove T. L., Hager B. H., Lee D-C., and Wiechert U. (2006) Thermal and magmatic history of the Moon. In New Views of the Moon. Pp. 365-518. Jolliff B. L., Wieczorek M. A., Shearer C. K. Neal C. R. (eds) Mineralogical Society of America, Chantilly.

Shih C. -Y., Nyquist L. E., Dasch E. J., Bogard D. D., Bansal B. M., and Weismann H. (1993) Age of pristine noritic clasts from lunar breccias 15445 and 15455. Geochim. Cosmochim. Acta 57, 915-931.

Shirley, D. N. (1983) A partially molten magma ocean model. Proc. Lunar Planet. Sci. Conf. 13th, in J. Geophys. Res., 88, A519-A527.

Smith J. A., Anderson A. T., Newton R. C., Olsen E. J., Wyllie P. J., Crewe A. V., Isaacson M. S., and Johnson D. (1970) Petrologic history of the Moon inferred from petrography, mineralogy, and petrogenesis of Apollo 11 rocks. Proc. $1^{\text {st }}$ Lunar Planet. Sci. Conf., 1149-1162. 
Smith, J. V., Progressive differentiation of a growing moon, Proc. Lunar Planet. Sci. Conf. 12th, 979-990, 1980.

Snyder G. A., Taylor L. A., and Neal C. R. (1992) A chemical model for generating the source of mare basalts: Combined equilibrium and fractional crystallization of the lunar magmashpere. Geochim. Cosmochim. Acta 56, 3809-3823.

Snyder G. A., Taylor L., A., and Halliday A. N. (1995) Chronology and petrogenisis of the lunar highlands alkali suite: Cumulates from KREEP basalt crystallization. Geochim. et Cosmochim Acta 59, 1185-1203.

Sprung P., Kleine T., and Scherer E. E. (2013) Hafnium-Neodymium Isotopic Evidence for a Chondritic Composition of the Moon. $44^{\text {th }}$ Lunar. Planet. Sci. Conf. Abstr. $\# 1594$.

Solomon S. C. (1986) On the early thermal state of the Moon. In Origin of the Moon. pp. 435-452, W. K. Hartmann, R. J. Phillips, G. J. Taylor (eds.) Edwards Bros. Houston.

Stacey J. S. and Kramers J. D. (1975) Approximation of terrestrial lead isotope evolution by a two-stage model. Earth Planet. Sci. Lett. 26, 207-221.

Stewart D. B. (1975) Apollonian metamorphic rocks - The products of prolonged subsolidus equilibration. Lunar Conf. VI, 774-776 (abstr.).

Taylor S. R. (1982) Planetary science: A lunar perspective, 481 pp., Lunar and Planetary Institute, Houston.

Walker, D.(1983) Lunar and terrestrial crust formation, Proc. Lunar Planet. Sci. Conf. $14^{\text {th }}$, in J. Geophys. Res., 88, B17-B25.

Wanke H., Palme H., Baddenhausen H., Kruse H, and Spettel B. (1977) Element correlations and the bulk composition of the Moon. Phil Trans. Roy. Soc. A285, 4148.

Warren P. H. (1988) KREEP: Major-element diversity, trace-element uniformity (almost). Workshop on Moon in Transition: Apollo 14, KREEP, and evolved lunar rocks 106-110 (Abstr.). 
Warren P. H. and Wasson J. T. (1979) The origin of KREEP. Rev. Geophys. Space Phys. 17, 73-88.

Warren P. H., Taylor G. J., Keil K., Marshall C., and Wasson J. T. (1981) Foraging westward for pristine non-mare rocks: Complications for petrogenetic models. Proc. Lunar Planet. Sci. Conf. 12B, 21-40.

Wetherill, G. W. Possible slow accretion of the Moon and its thermal and petrological consequences (abstract), in Papers Presented to the Conference on Origins of Mare Basalts and Their Implications for Lunar Evolution, pp. 184-188, Lunar Science Institute, Houston, 1975.

Williamson J. H. (1968) Least-squares fitting of a straight line. Canadian J. Phys. 46, 1845-1847.

Wood J. A., Dickey J. S., Marvin U. B., and Powell B. N. (1970) Lunar anorthosites and a geophysical model of the Moon. Proc. 1st Lunar Planet. Sci Conf., 965-988.

York D. (1966) Least squares fitting of a straight line. Canadian J. Phys. 44, 1079-1086. 


\section{Figure captions}

Figure 1. Summary of $\mathrm{Sm}-\mathrm{Nd}, \mathrm{Rb}-\mathrm{Sr}$, and $\mathrm{Pb}-\mathrm{Pb}$ ages determined on lunar highlands rocks from Borg et al. (2015) from the data of 1. Borg et al., (1999), 2. Marks et al. (2014b), 3. Borg et al. (2011), 4. Norman et al (2003), 5. Nyquist et al. (2006), 6. Alibert et al. (1994), 7. Snyder et al. (1995), 8. Compston et al. (1975), 9. Carlson and Lugmair, (1981a), 10. Carlson and Lugmair (1981b), 11. Carlson et al. (2014), 12, 14, 16. Shih et al. (1993), 13. Edmunson et al. (2009), 15. Papanastassiou and Wasserburg (1975), 17. Lugmaor et al. (1976), 18. Edmunson et al. (2007), 19. this study, 20. Premo and Tatsumoto, 1992), 21. Nyquist et al. (2012), 22. Papanastassiou and Wasserburg (1976). All ages have been recalculated using Isoplot 4.15.

Figure 2. Rare earth element patterns measured on aliquots of digested mineral fractions. Data are normalized to chondritic values of Anders and Grevesse (1989). Good agreement between the patterns determined for the mineral fractions and those measured for Mg-suite samples in situ by ion microprobe (Papike et al., 1996) indicate the mineral fractions were not significantly contaminated with extraneous minerals.

Figure 3. Sm-Nd isochron diagrams for 76535. Ages calculated using IsoPlot 4.15 (Ludwig, 1991). A. ${ }^{147} \mathrm{Sm}^{-143} \mathrm{Nd}$ isochron yields an age of $4307 \pm 11 \mathrm{Ma}$ and an initial $\varepsilon^{143} \mathrm{Nd}$ of $-0.16 \pm 0.15$. Inset represents deviation of individual mineral fractions from isochron in epsilon units. B. ${ }^{146} \mathrm{Sm}^{142} \mathrm{Nd}$ isochron yields an age of $4299^{+29} /_{-35} \mathrm{Ma}$ and an initial $\varepsilon^{143} \mathrm{Nd}$ of $-0.60 \pm 0.12$ relative to the present day ${ }^{142} \mathrm{Nd} /{ }^{144} \mathrm{Nd}$ terrestrial value measured in this study of 1.141838. Inset represents deviation of individual mineral fractions from isochron in epsilon units. The age is calculated using ${ }^{146} \mathrm{Sm} \mathrm{t}_{\frac{1}{2}}=103 \mathrm{Ma}$ and an initial ${ }^{146} \mathrm{Sm} /{ }^{144} \mathrm{Sm}=0.00828$ (see Marks et al., 2014a and Boyet et al., 2010). 
Figure 4. Rubidium-strontium isochron diagram of mineral fractions from 76535. An age of $4279 \pm 52 \mathrm{Ma}$ is defined by the plagioclase, olivine, and Dark Mineral Fractions (DMF) I and II. The regression yields an initial ${ }^{87} \mathrm{Sr} /{ }^{86} \mathrm{Sr}$ ratio of $0.699100 \pm 0.000009$. Inset represents deviation of individual mineral fractions from isochron in epsilon units.

Figure 5. Plot of ages of 76535 determined by Sm-Nd, Rb-Sr (this study), Ar-Ar (Cassata and Borg 2015), and Pb-Pb (Premo and Tatsumoto, 1992) versus the estimated closure temperature for these isotopic systems (open error ellipses). The slope is calculated using IsoPlot 4.15 (Ludwig, 1991) and corresponds to a cooling rate of 76535 of $3.9 \pm 1.2^{\circ} \mathrm{C} / \mathrm{Ma}$ that is in good agreement with cooling rates estimated from the petrography by Nord (1976) and Stewart (1975) of 1-5 ${ }^{\circ} \mathrm{C} / \mathrm{Ma}$. Dashed line represent 2 sigma uncertainty on slope calculation. Data point for ages determined by Sm-Nd and $\mathrm{Pb}-\mathrm{Pb}$ for FAS sample 60025 (Borg et al. 2011) are plotted as filled error ellipses.

Figure 6. Plots of age versus initial $\varepsilon N d$ determined from Sm-Nd isochrons of 76535 (solids symbols) and 60025 (open symbols). Ages and initial Nd isotopic compositions are plotted for measured values determined on the isochrons (circles) and ages and initial $\mathrm{Nd}$ isotopic compositions calculated at the solidus temperatures (squares). A. Epsilon ${ }^{143} \mathrm{Nd}$ versus age diagram in which solid lines represent Nd growth curves. Single-stage evolution starts from chondritic Sm-Nd isotopic composition of Jacobsen and Wasserburg (1980). Both 76535 and 60025 lie on chondritic growth curve with ${ }^{147} \mathrm{Sm} /{ }^{144} \mathrm{Nd}=0.1967$. B. Epsilon ${ }^{142} \mathrm{Nd}$ versus age diagram in which single-stage growth curves are calculated using the terrestrial ${ }^{142} \mathrm{Nd} /{ }^{144} \mathrm{Nd}$ ratio. Both 76535 and 60025 lie within error of a single-stage chondritic growth curve with ${ }^{147} \mathrm{Sm} /{ }^{144} \mathrm{Nd}=$ 0.1967 . 
Table 1. Rare earth element abundances in $\mathbf{7 6 5 3 5}$ mineral fractions

\begin{tabular}{|c|c|c|c|c|c|c|c|c|}
\hline ppm & $\begin{array}{c}\text { Pyroxene } \\
\text { A } \\
\end{array}$ & $\begin{array}{c}\text { Pyroxene } \\
\text { B } \\
\end{array}$ & $\begin{array}{c}\text { Pyroxene } \\
2 \\
\end{array}$ & $\begin{array}{l}\text { Pyroxene } \\
\text { Combined }\end{array}$ & $\begin{array}{c}\text { Super Pure } \\
\text { Olivine }\end{array}$ & Plagioclase & DMF I & DMF II \\
\hline $\mathrm{La}$ & $\begin{array}{c}0.204 \pm \\
0.006\end{array}$ & $\begin{array}{c}0.267 \pm \\
0.007\end{array}$ & $\begin{array}{c}0.608 \pm \\
0.013\end{array}$ & $\begin{array}{c}0.369 \pm \\
0.009\end{array}$ & $\begin{array}{c}0.0123 \pm \\
0.0012\end{array}$ & $\begin{array}{c}2.030 \pm \\
0.064\end{array}$ & $\begin{array}{c}0.105 \pm \\
0.003\end{array}$ & $\begin{array}{c}0.159 \pm \\
0.005\end{array}$ \\
\hline $\mathrm{Ce}$ & $\begin{array}{c}0.615 \pm \\
0.016\end{array}$ & $\begin{array}{c}0.734 \pm \\
0.016\end{array}$ & $\begin{array}{c}1.549 \pm \\
0.021\end{array}$ & $\begin{array}{c}0.985 \pm \\
0.018\end{array}$ & $\begin{array}{c}0.0368 \pm \\
0.0012\end{array}$ & $\begin{array}{c}4.66 \pm \\
0.15\end{array}$ & $\begin{array}{c}0.289 \pm \\
0.006\end{array}$ & $\begin{array}{c}0.436 \pm \\
0.009\end{array}$ \\
\hline $\operatorname{Pr}$ & $\begin{array}{c}0.112 \pm \\
0.013\end{array}$ & $\begin{array}{c}0.113 \pm \\
0.005\end{array}$ & $\begin{array}{c}0.223 \pm \\
0.008\end{array}$ & $\begin{array}{c}0.150 \pm \\
0.009\end{array}$ & $\begin{array}{c}0.0058 \pm \\
0.0004\end{array}$ & $\begin{array}{c}0.581 \pm \\
0.026\end{array}$ & $\begin{array}{c}0.0441 \pm \\
0.0021\end{array}$ & $\begin{array}{c}0.0636 \pm \\
0.0031\end{array}$ \\
\hline $\mathrm{Nd}$ & $\begin{array}{c}0.772 \pm \\
0.019\end{array}$ & $\begin{array}{c}0.709 \pm \\
0.049\end{array}$ & $\begin{array}{c}1.246 \pm \\
0.084\end{array}$ & $\begin{array}{c}0.906 \pm \\
0.050\end{array}$ & $\begin{array}{c}0.0287 \pm \\
0.0033\end{array}$ & $\begin{array}{c}2.615 \pm \\
0.038\end{array}$ & $\begin{array}{c}0.221 \pm \\
0.007\end{array}$ & $\begin{array}{c}0.331 \pm \\
0.011\end{array}$ \\
\hline $\mathrm{Sm}$ & $\begin{array}{c}0.623 \pm \\
0.048\end{array}$ & $\begin{array}{c}0.440 \pm \\
0.033\end{array}$ & $\begin{array}{c}0.676 \pm \\
0.015\end{array}$ & $\begin{array}{c}0.561 \pm \\
0.031\end{array}$ & $\begin{array}{c}0.0110 \pm \\
0.0021\end{array}$ & $\begin{array}{c}0.613 \pm \\
0.026\end{array}$ & $\begin{array}{c}0.099 \pm \\
0.002\end{array}$ & $\begin{array}{c}0.151 \pm \\
0.011\end{array}$ \\
\hline $\mathrm{Eu}$ & $\begin{array}{c}0.019 \pm \\
0.003\end{array}$ & $\begin{array}{c}0.027 \pm \\
0.003\end{array}$ & $\begin{array}{c}0.135 \pm \\
0.004\end{array}$ & $\begin{array}{c}0.062 \pm \\
0.004\end{array}$ & $\begin{array}{c}0.0012 \pm \\
0.0004\end{array}$ & $\begin{array}{l}1.071 \pm \\
0.0034\end{array}$ & $\begin{array}{c}0.0243 \pm \\
0.0006\end{array}$ & $\begin{array}{c}0.0372 \pm \\
0.0009\end{array}$ \\
\hline $\mathrm{Gd}$ & $\begin{array}{c}1.581 \pm \\
0.048\end{array}$ & $\begin{array}{c}1.036 \pm \\
0.049\end{array}$ & $\begin{array}{c}1.465 \pm \\
0.084\end{array}$ & $\begin{array}{c}1.304 \pm \\
0.058\end{array}$ & $\begin{array}{c}0.0135 \pm \\
0.0008\end{array}$ & $\begin{array}{c}0.626 \pm \\
0.013\end{array}$ & $\begin{array}{c}0.156 \pm \\
0.003\end{array}$ & $\begin{array}{c}0.245 \pm \\
0.005\end{array}$ \\
\hline $\mathrm{Tb}$ & $\begin{array}{c}0.526 \pm \\
0.013\end{array}$ & $\begin{array}{c}0.329 \pm \\
0.003\end{array}$ & $\begin{array}{c}0.449 \pm \\
0.015\end{array}$ & $\begin{array}{c}0.414 \pm \\
0.01\end{array}$ & $\begin{array}{c}0.0046 \pm \\
0.0004\end{array}$ & $\begin{array}{c}0.0897 \pm \\
0.0064\end{array}$ & $\begin{array}{c}0.0446 \pm \\
0.0008\end{array}$ & $\begin{array}{c}0.0668 \pm \\
0.0012\end{array}$ \\
\hline Dy & $\begin{array}{c}4.79 \pm \\
0.18\end{array}$ & $\begin{array}{c}3.03 \pm \\
0.15\end{array}$ & $\begin{array}{c}4.14 \pm \\
0.14\end{array}$ & $\begin{array}{c}3.80 \pm \\
0.15\end{array}$ & $\begin{array}{c}0.0050 \pm \\
0.0004\end{array}$ & $\begin{array}{c}0.451 \pm \\
0.017\end{array}$ & $\begin{array}{c}0.375 \pm \\
0.001\end{array}$ & $\begin{array}{c}0.564 \pm \\
0.016\end{array}$ \\
\hline Ho & $\begin{array}{c}1.262 \pm \\
0.048\end{array}$ & $\begin{array}{c}0.807 \pm \\
0.024\end{array}$ & $\begin{array}{c}1.057 \pm \\
0.042\end{array}$ & $\begin{array}{c}0.994 \pm \\
0.036\end{array}$ & $\begin{array}{c}0.0202 \pm \\
0.0004\end{array}$ & $\begin{array}{c}0.073 \pm \\
0.002\end{array}$ & $\begin{array}{c}0.107 \pm \\
0.002\end{array}$ & $\begin{array}{c}0.0149 \pm \\
0.003\end{array}$ \\
\hline $\mathrm{Er}$ & $\begin{array}{c}4.201 \pm \\
0.080\end{array}$ & $\begin{array}{c}2.732 \pm \\
0.049\end{array}$ & $\begin{array}{c}3.559 \pm \\
0.063\end{array}$ & $\begin{array}{c}3.341 \pm \\
0.061\end{array}$ & $\begin{array}{c}0.1248 \pm \\
0.0042\end{array}$ & $\begin{array}{c}0.158 \pm \\
0.004\end{array}$ & $\begin{array}{c}0.440 \pm \\
0.011\end{array}$ & $\begin{array}{c}0.543 \pm \\
0.013\end{array}$ \\
\hline $\mathrm{Tm}$ & $\begin{array}{c}0.671 \pm \\
0.029\end{array}$ & $\begin{array}{c}0.440 \pm \\
0.024\end{array}$ & $\begin{array}{c}0.559 \pm \\
0.015\end{array}$ & $\begin{array}{c}0.532 \pm \\
0.022\end{array}$ & $\begin{array}{c}0.0339 \pm \\
0.0017\end{array}$ & $\begin{array}{c}0.0152 \pm \\
0.0009\end{array}$ & $\begin{array}{c}0.094 \pm \\
0.003\end{array}$ & $\begin{array}{c}0.100 \pm \\
0.003\end{array}$ \\
\hline $\mathrm{Yb}$ & $\begin{array}{c}4.04 \pm \\
0.21\end{array}$ & $\begin{array}{c}2.68 \pm \\
0.12\end{array}$ & $\begin{array}{c}3.41 \pm \\
0.15\end{array}$ & $\begin{array}{c}3.23 \pm \\
0.15\end{array}$ & $\begin{array}{c}0.314 \pm \\
0.015\end{array}$ & $\begin{array}{c}0.069 \pm \\
0.003\end{array}$ & $\begin{array}{c}0.723 \pm \\
0.030\end{array}$ & $\begin{array}{c}0.698 \pm \\
0.029\end{array}$ \\
\hline $\mathrm{Lu}$ & $\begin{array}{c}0.601 \pm \\
0.019\end{array}$ & $\begin{array}{c}0.408 \pm \\
0.016\end{array}$ & $\begin{array}{c}0.492 \pm \\
0.021\end{array}$ & $\begin{array}{c}0.479 \pm \\
0.018\end{array}$ & $\begin{array}{c}0.0684 \pm \\
0.0017\end{array}$ & $\begin{array}{c}0.0077 \pm \\
0.0009\end{array}$ & $\begin{array}{c}0.141 \pm \\
0.004\end{array}$ & $\begin{array}{c}0.121 \pm \\
0.004\end{array}$ \\
\hline
\end{tabular}

Uncertainties are 2 standard deviations of three replicate analyses. DMF = Dark Mineral fraction. Px A, Px B, and Px 2 combined for isotopic analysis. 
Table 2. $76535 \mathrm{Sm}-\mathrm{Nd}$ isotopic data

\begin{tabular}{lcccccc}
\hline Fraction & $\begin{array}{c}\mathrm{Wt} \\
(\mathrm{mg})\end{array}$ & $\begin{array}{c}\mathrm{Sm} \\
(\mathrm{ppm})^{\mathrm{a}}\end{array}$ & $\begin{array}{c}\mathrm{Nd} \\
(\mathrm{ppm})^{\mathrm{a}}\end{array}$ & $\frac{{ }^{147} \mathrm{Sm}^{\mathrm{a}, \mathrm{d}}}{{ }^{144}}$ & ${ }^{143} N d{ }^{\mathrm{b}}$ & ${ }^{142} N d{ }^{\mathrm{b}}$ \\
\hline Plag & 360.7 & 0.622 & 2.558 & $0.14694 \pm 15$ & $0.511205 \pm 2$ & $1.141812 \pm 7$ \\
DMF I & 399.9 & 0.104 & 0.243 & $0.25947 \pm 26$ & $0.514431 \pm 4$ & $1.141837 \pm 12$ \\
DMF II & 350.0 & 0.171 & 0.399 & $0.2590 \pm 24$ & $0.514393 \pm 4$ & $1.141842 \pm 10$ \\
Px & 82.55 & 0.648 & 1.007 & $0.38897 \pm 39$ & $0.518117 \pm 6$ & $1.141882 \pm 14$ \\
\hline \multicolumn{5}{l}{ JNdi Nd Std 500 ng (N=6) }
\end{tabular}

$\mathrm{DMF}=$ Dark Mineral Fraction. All samples and standards run as $\mathrm{Nd}^{+}$.

a. Error limits apply to last digits and include a minimum uncertainty of $0.5 \%$ plus $50 \%$ of the blank correction for $\mathrm{Sm}$ and $\mathrm{Nd}$ added quadratically.

b. Normalized to ${ }^{146} \mathrm{Nd} /{ }^{144} \mathrm{Nd}=0.7219$. Uncertainties refer to last digits and are $2 \sigma_{\mathrm{m}}(2 \mathrm{x}$ standard error of measured isotopic ratios).

c. Uncertainties refer to last digits and are $2 \sigma_{\mathrm{p}} \quad(2 \mathrm{x}$ standard deviation of population of mass spectrometry runs on isotopic standard). Isochrons are calculated using either $2 \sigma_{\mathrm{p}}$ (from standard runs) or $2 \sigma_{\mathrm{m}}$ (from measured isotopic ratios), whichever is larger.

d. ${ }^{147} \mathrm{Sm} /{ }^{144} \mathrm{Nd}$ corrected for neutron capture using Sm isotopic composition measured on an unspiked plagioclase fraction. Sm isotopic composition is $\varepsilon^{149} \mathrm{Sm}=-16.5 \pm 0.10$ and $\varepsilon^{150} \mathrm{Sm}=$ $+26.7 \pm 0.15$.

Table 3. $76535 \mathrm{Rb}-\mathrm{Sr}$ isotopic data

\begin{tabular}{|c|c|c|c|c|c|}
\hline Fraction & $\begin{array}{l}\mathrm{Wt} \\
(\mathrm{mg})\end{array}$ & $\begin{array}{c}\mathrm{Rb} \\
(\mathrm{ppm})\end{array}$ & $\begin{array}{c}\mathrm{Sr} \\
(\mathrm{ppm})\end{array}$ & $\frac{{ }^{87} R b}{{ }^{86} S r}$ & ${\frac{{ }^{87} S r}{{ }^{86} S r}}^{\mathrm{b}}$ \\
\hline Plag & 7.36 & 0.2882 & 149.2 & $0.00559 \pm 6$ & $0.699446 \pm 5$ \\
\hline DMF I & 350.0 & 0.0471 & 5.98 & $0.02275 \pm 23$ & $0.700491 \pm 13$ \\
\hline DMF II & 399.9 & 0.0447 & 6.03 & $0.02145 \pm 21$ & $0.700435 \pm 5$ \\
\hline $\mathrm{Px}$ & 82.55 & 0.0402 & 10.7 & $0.01086 \pm 11$ & $0.699514 \pm 5$ \\
\hline SPO & 467.3 & 0.00097 & 0.0321 & $0.08782 \pm 24$ & $0.704565 \pm 9$ \\
\hline \multicolumn{5}{|c|}{ NBS-987 500 ng $(\mathrm{N}=6)$} & $0.710247 \pm 9^{c}$ \\
\hline
\end{tabular}

$\mathrm{DMF}=$ Dark Mineral Fraction, SPO $=$ Super Pure Olivine. The long term

${ }^{85} \mathrm{Rb} /{ }^{87} \mathrm{Rb}$ measured on 30 runs of NBS-984 Rb standard $=2.603 \pm 17\left(2 \sigma_{\mathrm{p}}\right)$ and were used to corrected for instrument mass fractionation.

a. Error limits apply to last digits and include a minimum uncertainty of $1 \%$ plus $50 \%$ of the blank correction for $\mathrm{Rb}$ and $\mathrm{Sr}$ added quadratically.

b. Normalized to ${ }^{86} \mathrm{Sr} /{ }^{88} \mathrm{Sr}=0.1194$. Uncertainties refer to last digits and are $2 \sigma_{\mathrm{m}}$ ( 2 x standard error of measured isotopic ratios).

c. Uncertainties refer to last digits and are $2 \sigma_{\mathrm{p}} \quad(2 \mathrm{x}$ standard deviation of population of mass spectrometry runs on isotopic standard). Isochron are calculated using either $2 \sigma_{\mathrm{p}}$ (from standard runs) or $2 \sigma_{\mathrm{m}}$ (from measured isotopic ratios), whichever is larger. 


\section{$76535 / 335$}
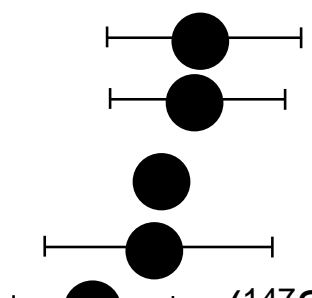

$\left({ }^{147} \mathrm{Sm}\right){ }^{17}$

Mg-Suite

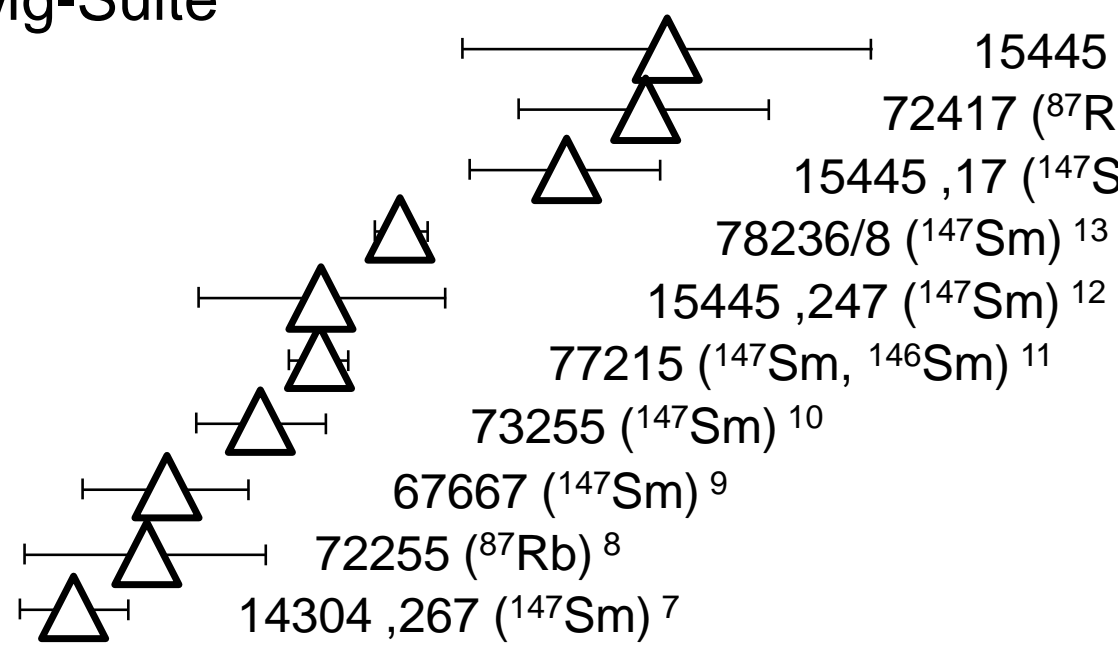

$\longmapsto\left({ }^{87} R b\right)^{21}$

$\left({ }^{147} \mathrm{Sm}\right)^{21}$

$\left({ }^{147} \mathrm{Sm}\right){ }^{20}$

$\left({ }^{147} \mathrm{Sm},{ }^{146} \mathrm{Sm},{ }^{87} \mathrm{Rb}\right){ }^{19}$

$\left({ }^{147} \mathrm{Sm}\right){ }^{18}$

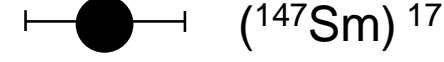

FAS

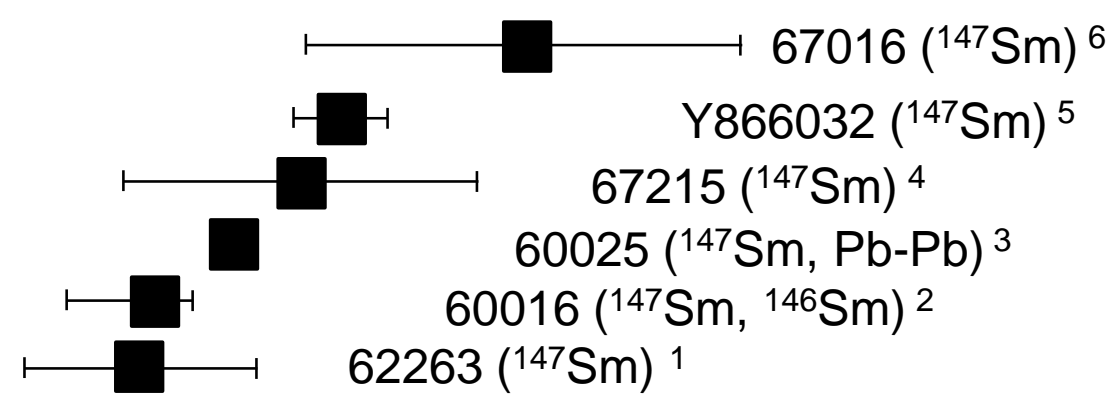

$\begin{array}{llll}4000 & 4200 & 4400 \quad 4567\end{array}$

Figure 1 


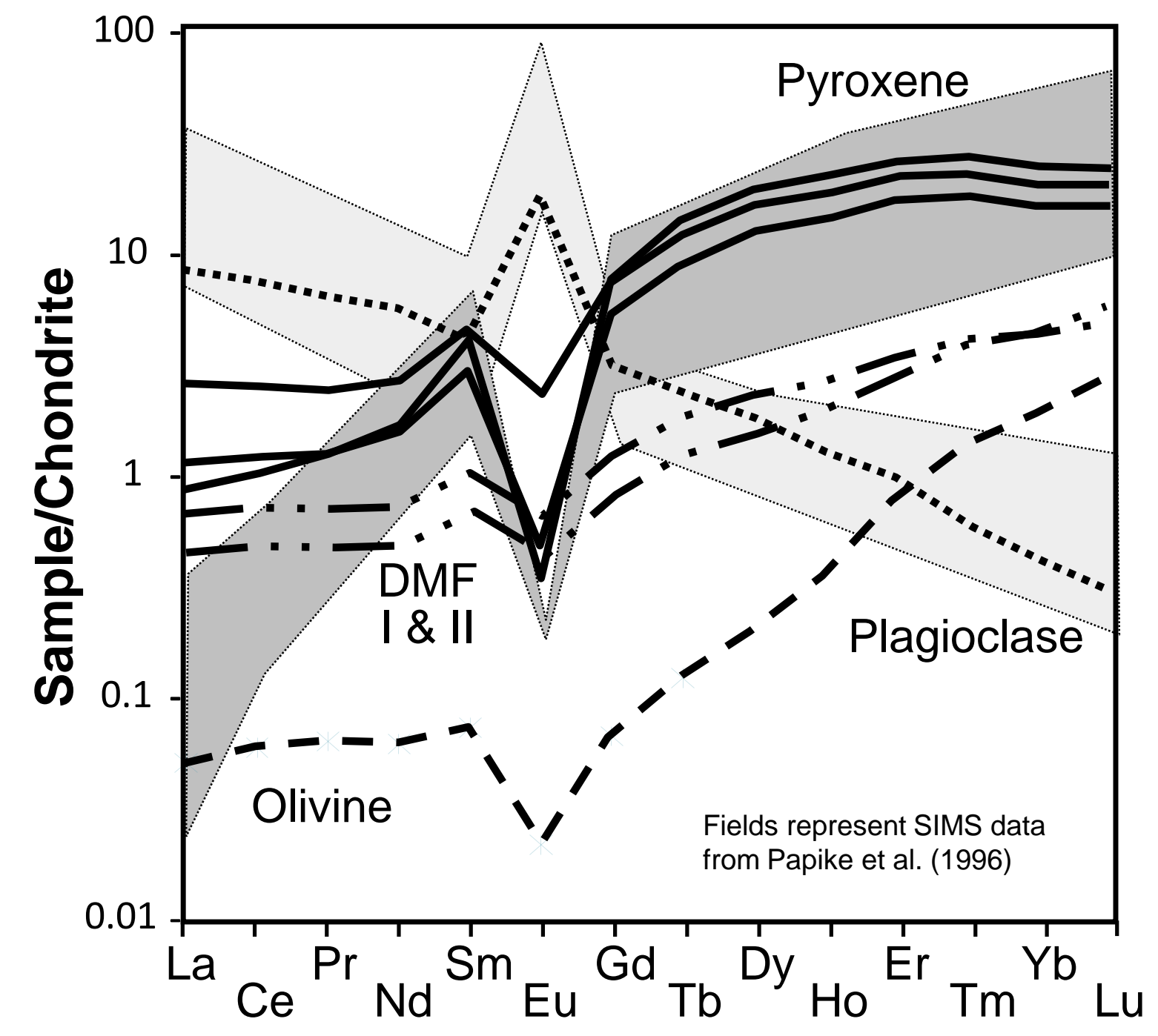

Figure 2 

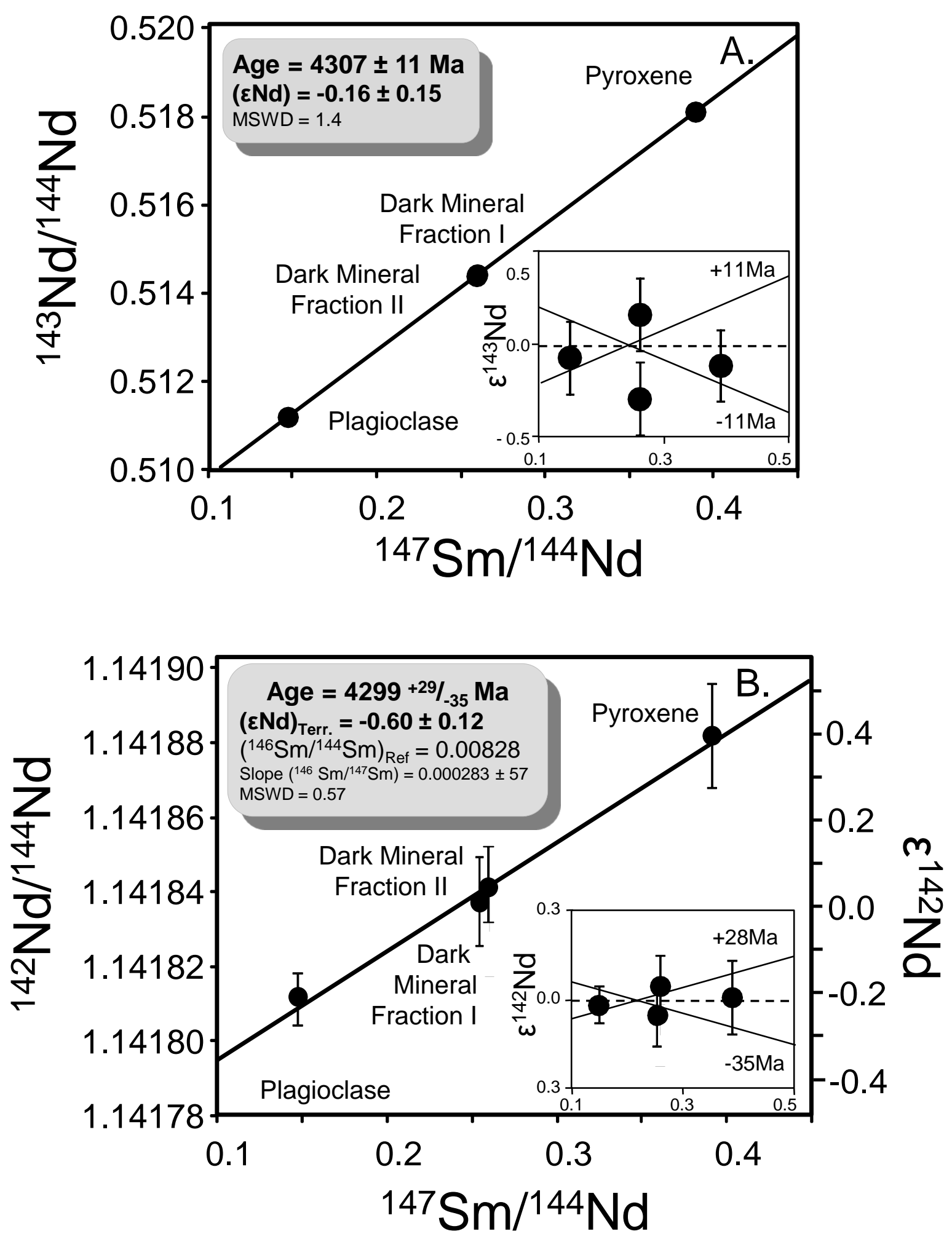

Figure 3 


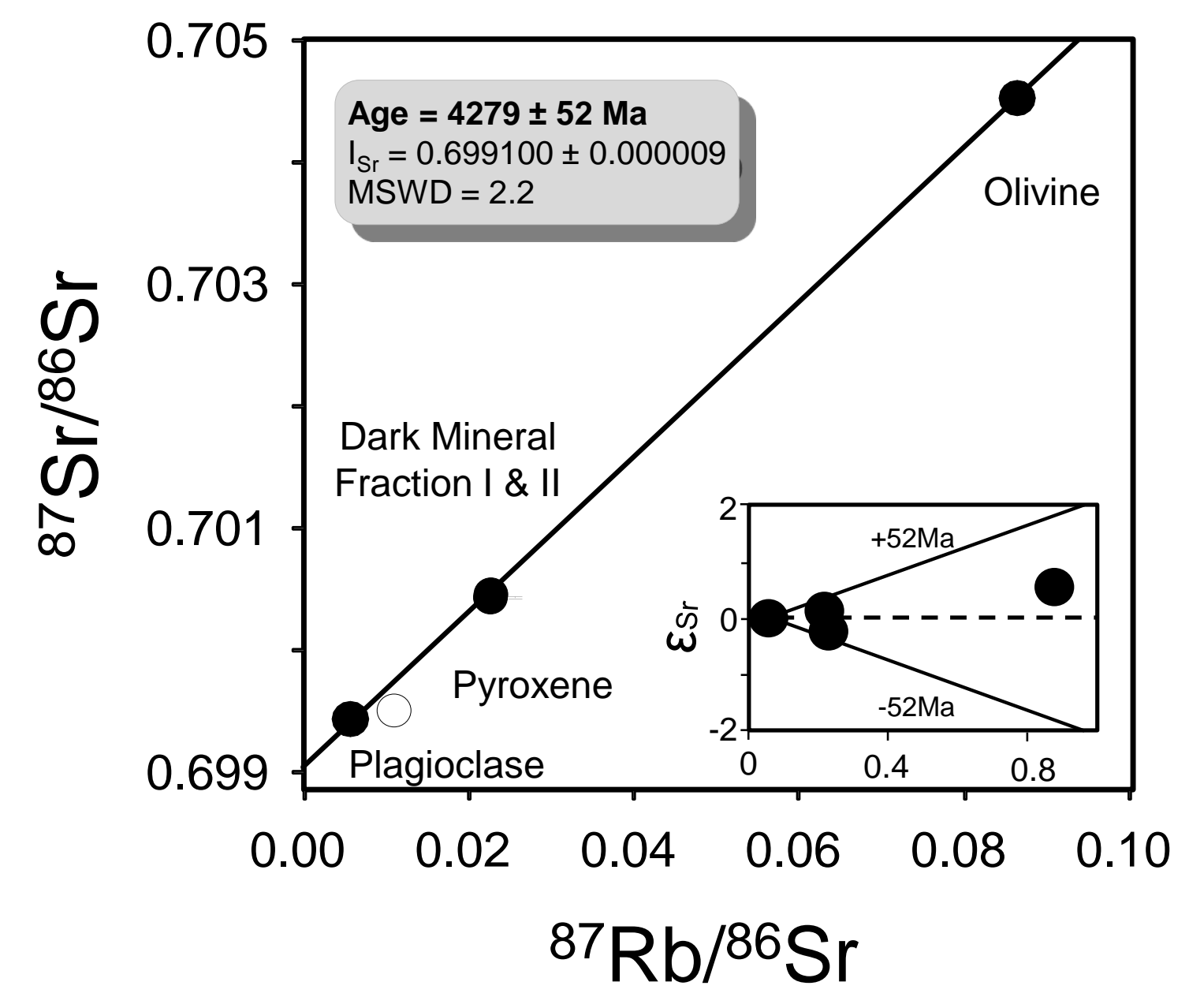

Figure 4 


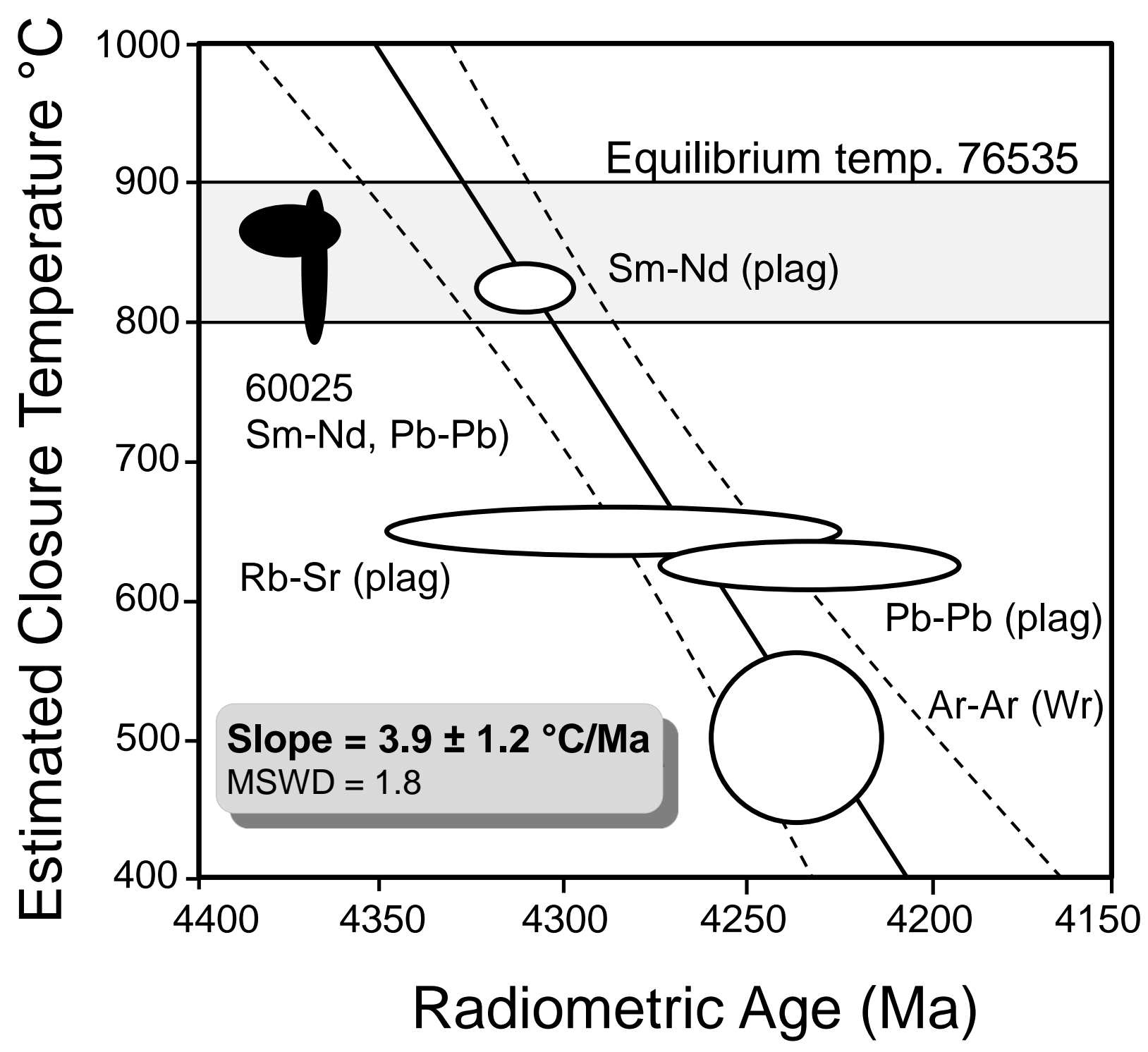

Figure 5 


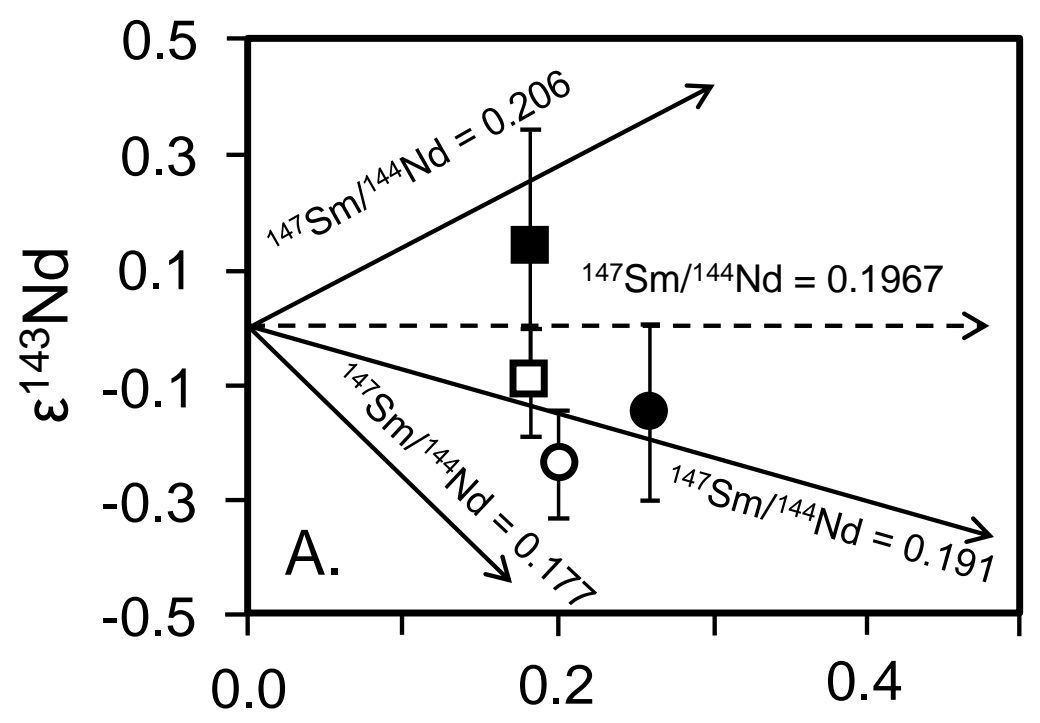

Time from $4567 \mathrm{Ma}$

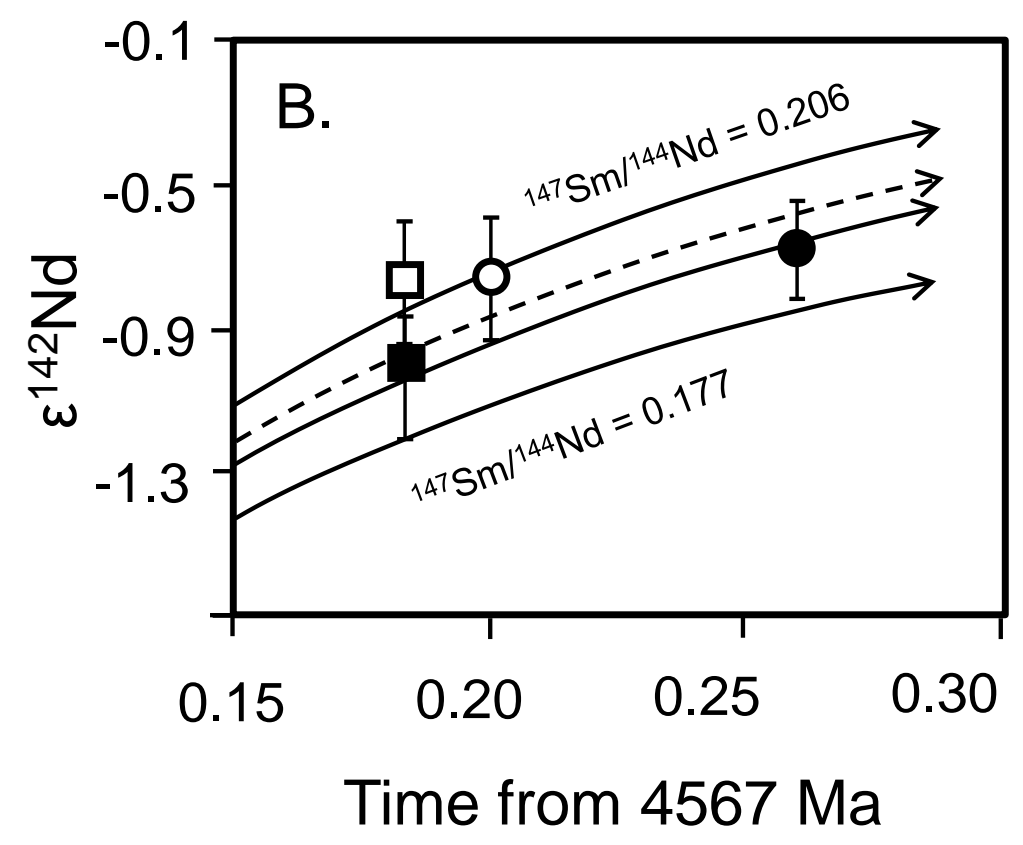

Figure 6 